\title{
Medicinal plants with cardiovascular effects (part 2): plant based review
}

\author{
Prof Dr Ali Esmail Al-Snafi \\ Department of Pharmacology, College of Medicine, Thi qar University, Iraq.
}

\begin{abstract}
Previous researches revealed that many medicinal plants affected cardiovascular function and can be utilize for therapeutic purposes. This review will highlight the cardiac, cardioprotective, vascular, hypolipidemic, fibrinolytic and anti platelet aggregating of medicinal plants as a second part of our previous review.
\end{abstract}

Keywords: medicinal plants, herbs, cardiac, cardioprotective, vascular, hypolipidemic, fibrinolytic and anti platelet aggregating

\section{Introduction:}

There were substantial evidences that many medicinal plants decreased the risk of cardiovascular diseases. Previous reviews revealed that many medicinal plants affected cardiovascular function and can be utilize for therapeutic purposes. They produced wide range of cardiovascular effects included cardiac, cardioprotective, vascular, hypolipidemic, fibrinolytic and anti platelet aggregating effects [1-2]. These plants included: Achillea santolina [3], Adonis vernalis [4], Agrimonia eupatoria [5], Agropyron repens [6], Alhagi maurorum [7], Allium cepa [8], Allium porrum[8], Allium sativum [8], Aloe vera [9], Alpinia galangal [10], Althaea rosea [11], Ammi visnaga [12], Anchusa strigosa [13], Anethum graveolens [14], Anthemis nobelis [15], Apium graveolens [16], Arachis hypogaea [17-18], Aristolochia maurorum [19], Asclepias curassavica [20], Asparagus officinalis [21], Avena sativa [22], Bacopa monnieri [23], Bauhinia variegate [24], Bellis perennis [25], Benincasa hispida [26], Brassica nigra [27], Brassica rapa [27], Bryophyllum calycinum [28], Caccinia crassifolia [29], Caesalpinia crista [30], Calendula officinalis [31], Calotropis procera [32], Capparis spinosa [33], Capsicum annuum [34], Capsicum frutescens [34], Carthamus tinctorius [35-36], Carum carvi [37], Casuarina equisetifolia [38], Celosia cristata [39], Centaurea cyanus [40] and Cheiranthus cheiri [30]. This review was designed to cover the cardiac, cardioprotective, vascular, hypolipidemic, fibrinolytic and anti platelet aggregating of medicinal plants as a second part of our previous review.

\section{Medicinal plants with cardiovascular effects: \\ Cicer arietinum}

Treatment of legumin of Cicer arietinum with alcalase yielded a hydrolysate that inhibited the angiotensin I converting enzyme with an $\mathrm{IC}_{50}$ of $0.18 \mathrm{mg} / \mathrm{ml}$. Fractionation of this hydrolysate by reverse phase chromatography afforded six inhibitory peptides with $\mathrm{IC}_{50}$ values ranging from 0.011 to $0.021 \mathrm{mg} / \mathrm{ml}$. All these peptides contain the amino acid methionine and are also rich in other hydrophobic amino acids. Hydrolysates of chickpea legumin obtained by treatment with alcalase are a good source of peptides with angiotensin1 converting enzyme inhibitory activity [41-42].

The hypocholesterolaemic and antioxidant activities of chickpea protein were studied. All hydrolysates tested exhibited better hypocholesterolaemic activity when compared with chickpea protein isolate. The highest cholesterol micellar solubility inhibition $(50 \%)$ was found after $60 \mathrm{~min}$ of treatment with alcalase followed by $30 \mathrm{~min}$ of hydrolysis with flavourzyme. To test antioxidant activity of chickpea proteins three methods were used: $\beta$-carotene bleaching method, reducing power and 2,2-diphenyl-1-picrylhydrazyl (DPPH) radicalscavenging effect. Chickpea hydrolysates showed better antioxidant activity in all assays, especially reducing power and DPPH scavenging effect than chickpea protein isolate [43].

\section{Cichorium intybus}

Pharmacological study of eight varieties of Cichorium intybus on isolated toad's heart showed that the eight varieties have a quinidine like action, but with variable potency. The site of action was determined on a representative sample where it produced effect after blocking the ganglia and after atropinisation [44-45].

The vasorelaxant activities of chicoric acid from Cichorium intybus along with caffeic acid were studied in isolated rat aorta strips. chicoric acid, a diester composed of (S,S)-tartaric acid and caffeic acid, showed slow relaxation activity against norepinephrine (NE)-induced contraction of rat aorta with/without endothelium. These compound did not affect contraction induced by a high concentration of potassium $\left(60 \mathrm{mM} \mathrm{K} \mathrm{K}^{+}\right.$, while it 
inhibited NE-induced vasocontraction in the presence of nicardipine. The results revealed that the inhibition of NE-induced vasocontraction is due to a decrease in calcium influx from the extracellular space, which enhanced by NE [46].

The detoxification role of Cichorium intybus was evaluated in Cisplatin - induced toxicity on electrolyte balance in rats. At a dose of $500 \mathrm{mg} / \mathrm{kg}$ bw of Cichorium intybus ethanolic extract pretreatment showed partial counter action on the electrolytes imbalances and $\mathrm{Na}^{+}-\mathrm{K}^{+}$-ATPase activity [47].

Caffeine-free chicory coffee is a rich source of plant phenolics, including caffeic acid, which inhibits in vitro platelet aggregation, and also phenylpyruvate tautomerase enzymatic activity of the proinflammatory cytokine, macrophage migration inhibitory factor (MIF). The cardiovascular benefits of chicory coffee consumption were assessed on 27 healthy volunteers, who consumed $300 \mathrm{ml}$ chicory coffee every day for 1 week. The dietary intervention produced variable effects on platelet aggregation, depending on the inducer used for the aggregation test. Whole blood and plasma viscosity were both significantly decreased, along with serum MIF levels, after 1 week of chicory coffee consumption. Moreover, significant improvements were seen in red blood cell deformability. No changes in hematocrit, fibrinogen level or red blood cell counts were detected. The full spectrum of these effects is unlikely to be attributable to a single compound present in chicory coffee, nevertheless, the phenolics, including caffeic acid, are expected to play a substantial role [48].

\section{Cistanche tubulosa}

The hypocholesterolemic effect of the aqueous ethanol extract (CTE) of the roots of Cistanche tubulosa was evaluated in mice using gene chip and RT-PCR analysis of the livers of mice given CTE (400 $\mathrm{mg} / \mathrm{kg}$ ) for 14 days. The administration of CTE $(400 \mathrm{mg} / \mathrm{kg})$ for 14 days significantly suppressed serum cholesterol elevation in high cholesterol diet-fed mice. The mRNA expressions of VLDL receptor and cytochrome P450 SCC were significantly enhanced. In addition, acteoside, a major constituent of CTE, was found to enhance the mRNA expressions of apolipoprotein B, VLDL receptor, and cytochrome P450 SCC in HepG2 hepatocytes. According to these results, the authors concluded that CTE affected the mRNA expressions of molecules related to cholesterol transport and metabolism and exhibited hypocholesterolemic activity in diet-induced hypercholesterolemia mice. Acteoside was involved in the hypocholesterolemic activity of CTE [49].

The vasorelaxant activity of echinacoside, a phenylethanoid glycoside isolated from Cistanche tubulosa, and its possible underlying mechanism on isolated rat thoracic aortic rings pre-contracted with phenylephrine (PE, 1 microM) and $\mathrm{KCl}(60 \mathrm{mM})$ was investigated. Echinacoside (30-300 microM) exhibited an acute relaxation in endothelium-intact rings in a concentration-dependent manner, while this relaxation was significantly inhibited in endothelium-denuded condition and in the presence of the endothelial nitric oxide synthase (eNOS) inhibitor, N(W)-nitro-L-arginine methyl ester (L-NNA, 100 microM), an unselective soluble guanylate cyclase blocker, methylene blue (10 microM) and the selective sGC inhibitor $1 \mathrm{H}-[1,2,4]$ oxadiazolo[4,3- A]quinoxalin-1-one (ODQ, 1 microM); in addition, atropine (1 microM), a selective muscarinic receptor antagonist, partially affected the relaxation. However, the cyclooxygenase inhibitor indomethacin $(5$ microM) had no influence on the relaxant action. Echinacoside enhanced the cyclic guanosine monophosphate (cGMP) production in aortic rings contracted with PE. The authors concluded that echinacoside mediates the endothelium-dependent vasodilator action in rat thoracic aortic rings through nitric oxide (NO)-cGMP pathway [50].The methanolic extract from the dried stems of Cistanche tubulosa showed inhibitory effect on contractions induced by noradrenaline in isolated rat aortic strips. From the extract, new phenylethanoid oligoglycoside constituents, kankanosides F and G, and an acylated oligosugar, kankanose, were isolated together with 14 known compounds. Kankanoside F, kankanose, echinacoside, acteoside, and cistanoside F, showed vasorelaxant activity [51].

\section{Citrullus colocynthis}

The hypolipidemic effect of Citrullus colocynthis was studied clinically. One hundred dislipidemic patients were randomly divided into two treated and placebo groups. They were treated daily with powdered seeds of Citrullus colocynthis $(300 \mathrm{mg})$ and placebo for 6 weeks. Lipid profile, SGOT and SGPT were measured at the beginning and the end of the treatment period. Significant differences within and between treated and placebo groups was recorded in TG and cholesterol $(\mathrm{p}<0.05)$. A daily intake of $300 \mathrm{mg} / \mathrm{day}$ of powdered seeds of Citrullus colocynthis can lower the triglyceride and cholesterol concentration significantly in nondiabetic hyperlipidemic patients [52-53].The effects of the fixed oil extracted from the seeds of Citrullus colocynthis on blood homeostasis and body weight were studied in rats. Animals were given daily $4 \%$ of dietary regimen of the Citrullus colocynthis oil for 8 weeks, they showed significant slowdown of the body weight evolution comparatively to the animal in control group received $4 \%$ of sunflower oil. Furthermore, Colocynth oil treatment had a tendency to increase food intake feces output, and lipid in feces significantly. In parallel, the serum cholesterol, triglycerides, ALP levels and the count of erythrocytes and haematocrit level decreased significantly by $15.38,22.22,46.29,14.97$ and $14.17 \%$, respectively compared to control values; 
while AST level increased significantly by $21.71 \%$. These results support the suggestion of using Citrullus colocynthis oil as a treatment for dyslipidemia and hyperglycemia, and related abnormalities [54]. The inhibitory effect of Citrullus colocynthis (CCT) on inflammatory cytokines secreted in obesity conditions was studied in mice. Control group was fed with normal diet (N-D) for 42 days alone or plus $50 \mathrm{mg} / \mathrm{kg}$ hydroalcoholic (H-A) extract of CCT. The obese mice were given high fat diet (H-F-D) for 42 days alone or plus CCT extract. Food intake and body weight were recorded each week and expression of TNF- $\alpha$, IL- 6 and IL-10 in serum were assayed after every two weeks. CCT extract reduced body weight by $4.02 \%(\mathrm{p}>0.05)$ and food intake by $3.52 \%$ ( $>>0.05$ ), but dramatically decreased expression of TNF- $\alpha$ 44.83(p<0.001), IL-6 30.23(p< $0.001)$ and marginally increased IL-10 $5.31(\mathrm{p}>0.05)$ in obese mice. Accordingly, CCT extract did not show anti-obesity effects, it could have an anti-inflammatory effect through down regulation of obesity-associated pro-inflammatory cytokines [55].

\section{Citrus species}

According to World Health Organization's recent report, citrus fruits offer protection against cardiovascular diseases by reducing levels of homocysteine. Orange fruit contained vitamin $\mathrm{C}$, carotenoids and flavonoids, which were cardio- protective. Cholesterol lowering effect of orange was produced by limonene. Furthermore, polymethoxylated flavones (PMFs) were present in citrus fruit peel, which can lower cholesterol more effectively than some prescription drugs, without showing any side effect. Although, a variety of citrus fruits contain PMFs, the most common PMFs were tangeretin and nobiletin. PMFs work like statin drugs that inhibit the synthesis of cholesterol and triglycerides inside the liver. However, a tablespoon or so of the peel of orange each day, may be a practical way of achieving some cholesterol-lowering benefits [56]. Hesperidin, a bioflavonoid, was an abundant and inexpensive by-product of citrus cultivation. A deficiency of this substance in the diet has been linked with abnormal capillary leakiness as well as pain in the extremities causing aches, weakness and night leg cramps. No signs of toxicity have been observed with the normal intake of hesperidin or related compounds [57] The effect of drinking the juice of two different citrus fruits on vascular neointima formation was studied using a cuff-induced vascular injury mouse model. Male C57BL6 mice were divided into five groups as follows: 1) Control (water) (C), 2) $10 \%$ citrus unshiu (CU) juice (CU10), 3) $40 \%$ CU juice (CU40), 4) $10 \%$ citrus iyo (CI) juice (CI10), and 5) 40\% CI juice (CI40). After drinking them for 2 weeks from 8 weeks of age, cuff injury was induced by polyethylene cuff placement around the femoral artery. Neointima formation was significantly attenuated in CU40, CI10 and CI40 compared with C. However, no remarkable preventive effect was observed in CU10. The increases in levels of various inflammatory markers including cytokines such as monocyte chemotactic protein-1, interleukin-6 (IL-6), IL-1 $\beta$, and tumor necrosis factor- $\alpha$ in response to vascular injury did not differ significantly between C, CU10 and CI10. The increases in cell proliferation and superoxide anion production were markedly attenuated in CI10, but not in CU10 compared with C. The increase in phosphorylated ERK expression was markedly attenuated both in CU10 and CI10 without significant difference between CU10 and CI10. Accumulation of immune cells did not differ between CU10 and CI10. The results indicate that drinking citrus fruit juice attenuates vascular remodeling partly via a reduction of oxidative stress [58]. The cardiovascular effects of Citrus aurantifolia fruit were studied experimentally. The anti-hypertensive effect was tested on three experimental hypertensive models including cadmium induced hypertensive model, glucose induced hypertensive model, Egg feed diet induced hypertensive model, and normotensive model. The systolic pressure, diastolic pressure, mean blood pressure and heart rate of Spargue Daweley rats were measured by tail cuff method from the tail of rats using non-invasive blood pressure instrument and body weights were also measured. Three different doses were used for screening 0.25 , 05, and $0.75 \mathrm{~g} / \mathrm{kg}$, orally given and there effects on normotensive rats were observed at $2 \mathrm{hr}, 4 \mathrm{hr}$ and $6 \mathrm{hr}$ intervals. The dose of $0.75 \mathrm{~g} / \mathrm{kg}$ was selected because it significantly reduced the mean blood pressure, systolic blood pressure, diastolic blood pressure, and heart rate. The methanol extract of Citrus aurantifolia, administered at the dose of $0.75 \mathrm{mg}$ orally, significantly $(\mathrm{p}<0.01)$ reduced systolic blood pressure, mean blood pressure, diastolic blood pressure, heart rate and body weight of Spargue Dawely rats in both normotensive and hypertensive experimental models when compared to control groups [59].

The effects of an aqueous extract of Citrus aurantifolia on arterial blood pressure and on isolated heart and aorta activities was evaluated experimentally. Rabbits were used for the study on the arterial blood pressure using a Ludwig manometer. Albino Wistar rats were used for the isolated heart and aorta activities using isolated organ bath systems. Aqueous extract of Citrus aurantifolia $(4 \mathrm{mg} / \mathrm{kg}-16 \mathrm{mg} / \mathrm{kg}$ bw) produced a dosedependent and significant decrease in rabbit blood pressure $(\mathrm{p}<0.05)$. This hypotension was not prevented by atropine $(2 \mathrm{mg} / \mathrm{kg} \mathrm{bw}, \mathrm{p}>0.05)$. Aqueous extract $(4 \mathrm{mg} / \mathrm{kg}-16 \mathrm{mg} / \mathrm{kg}$ bw) was dose-dependently reduced hypertension evoked by adrenalin $(30 \mu \mathrm{g} / \mathrm{kg} \mathrm{bw})$. The extract also induced both negative inotropic and chronotropic effects on the heart contractile activity. The extract induced a dose dependent relaxation of contractions produced by adrenalin or by $\mathrm{KCl}$. Aqueous extract of Citrus aurantifolia evoked vasorelaxant effects were totally abolished by removal of the endothelium layer or by a pretreatment with L-NAME [60]. 
In vitro / in vivo study was designed to determine the effect of Citrus limon on blood parameters, coagulation and anticoagulation factors. In vitro tests revealed highly significant increase in thrombin time and activated partial thromboplastin time by Citrus limon, whereas fibrinogen concentration was significantly reduced in comparison to control, however prothrombin time was not affected significantly. In vivo testing of Citrus limon was carried out at three different doses $(0.2,0.4$ and $0.6 \mathrm{ml} / \mathrm{kg})$ in healthy rabbits. Significant changes were observed in hematological parameters such as erythrocytes, hemoglobin and mean corpuscular hemoglobin concentration. Bleeding time and thrombin time were significantly prolonged and there was increase in protein $\mathrm{C}$ and thrombin antithrombin complex levels. These results may be due to inactivation of thrombin because it significantly decreased fibrinogen concentration and inhibited platelet aggregation. Citrus limon showed maximal anticoagulant effect at $0.4 \mathrm{ml} / \mathrm{kg}$, which suggest that Citrus limon possessed an anti-thrombin component and could prevent thrombosis and playing a cardioprotective role [61]. The protective effect of the ethanolic extract of Otroj, Citrus medica (EEOT) against isoproterenol (ISO)-induced cardiotoxicity was evaluated in rats. Rats were administered EETO (250 and 500 $\mathrm{mg} / \mathrm{kg}$ ) or vehicle orally for 15 days along with ISO $(85 \mathrm{mg} / \mathrm{kg}, \mathrm{sc})$ on the $14^{\text {th }}$ and $15^{\text {th }}$ day. ISO induced cardiac dysfunction, increased lipid peroxidation and alteration of myocyte-injury specific marker enzymes. ISO also showed an increase in levels of plasma cholesterol, triglycerides (TG), LDL-C, and VLDL-C. Moreover, the histological investigations showed myocardial necrosis and inflammation. EETO treatment brought the above parameters towards normal level. Moreover, in vitro DPPH radical scavenging and $\beta$ carotene-linoleic acid tests of the EEOT exhibited a notable antioxidant activity in both assays used. In addition, histopathological examination reconfirmed the protective effects of EEOT. Accordingly $C$. medica alleviates myocardial damage in ISO-induced cardiac injury and demonstrates cardioprotective potential [62].The antihypertensive effect of $C$. medica limetta leaves was investigated against the acute response of blood pressure to angiotensin II administration The results showed that different concentrations of the aqueous extract prevented the raise of systolic blood pressure ( $\mathrm{p} \leq 0.001$ vs. vehicle), diastolic blood pressure $(\mathrm{p} \leq 0.0002$ vs. vehicle) and mean blood pressure ( $\mathrm{p} \leq 0.0000$ vs. vehicle); with a dose dependent effect for diastolic pressures at $125-500 \mathrm{mg} / \mathrm{kg}$ dosages. The 500 and $1000 \mathrm{mg} / \mathrm{kg}$ doses inhibited the action of Ang II in similar extent to telmisartan. Toxic signs or deaths were not observed in mice treated with a dose of $2000 \mathrm{mg} / \mathrm{kg}$ [63].Four-week consumption of orange juice in healthy middle-aged, normal-weight men reduced diastolic blood pressure (DBP) [64]. However, the effects of four-week intake of natural and commercial orange (Citrus sinensis) juice (CSJ) on blood pressure was evaluated in healthy volunteers. 22 healthy subjects were included and randomly divided into two groups. Group A consumed commercial CSJ during the first four-week period. After a twoweek washout period, they consumed natural CSJ for another four weeks. The procedure was reversed in group B. The participants were asked to drink $500 \mathrm{ml} /$ day of either natural or commercial CSJ twice a day with breakfast and dinner. After drinking commercial CSJ, diastolic and systolic blood pressure were significantly decreased $(5.13 \% ; \mathrm{P}=0.03$ and $-5.91 \% ; \mathrm{P}=0.003$, respectively). However, consumption of natural CSJ did not have significant effects on either diastolic or systolic blood pressure. Higher flavonoid, pectin, and essential oils content of concentrated products compared to natural juice might have been responsible for this effect [65].

An attempt was made to isolate hypotensive substances from a hot water extract of Citrus unshiu. Six flavonoid glycosides were isolated by repeated chromatography and gel filtration after extraction with butanol and treatment with lead subacetate. Each component was intravenously injected into SHR-SP rats $(1 \mathrm{mg} / 100 \mathrm{~g}$ body weight), 3,6-di-C-glucosylapigenin and rutin were found to lower their blood pressure [66].

The effect of Citrus aurantifolia peel essential oil was studied on serum triglyceride and cholesterols in Wistar rats. Thirty Wistar rats were divided into 5 groups: control, sham, and 3 experimental groups. The animals were treated in 2 phases: first, except for control group, which received normal saline, the rest of the groups were fed with a high cholesterol regimen to induce hyperlipidemia; then, the 3 experimental groups were treated with Citrus aurantifolia peel essential oil in 3 different doses: 25, 50, and $100 \mu 1 / \mathrm{kg}$. The sham group demonstrated a significant rise in mean serum triglyceride, cholesterol, and LDL level in comparison with the control group $(\mathrm{p}<0.05)$. The results of experimental groups treated with peel essential oil in 50 and $100 \mu 1 / \mathrm{kg}$ doses demonstrated a significant reduction in triglyceride, cholesterol, and LDL ( $<<0.01$ ) [67].

The effect of Citrus aurantifolia on hepatic lipidomics was studied in female albino rats, it was found that the fresh juice of lime had different effects on cholesterol, riacylglycerol and phospholipid concentrations of the liver. The low concentration of lime juice $(30 \mu \mathrm{l})$ did not showed considerable effect on cholesterol concentration of the liver. Increase in cholesterol concentration was observed only after applying a concentration of $60 \mu \mathrm{l}$. Beyond this concentration, cholesterol concentration was decreased. Therefore, it was demonstrated that peak stimulation for lime juice is $60 \mu \mathrm{l}$. Similar effect also occur for triacylglycerol concentration. However, it caused dose-dependent increase in phospholipids concentration [68].

Eriocitrin (eriodictyol 7-rutinoside), a powerful antioxidative flavonoid in lemon with lipid-lowering effects was evaluated in a rat model of high-fat diet to investigate its mechanism of action. A feeding experiments was conducted in zebrafish with diet-induced obesity. Oral administration of eriocitrin $(32 \mathrm{mg} / \mathrm{kg} / \mathrm{day}$ for 28 days $)$ improved dyslipidaemia and decreased lipid droplets in the liver. DNA microarray analysis revealed that 
eriocitrin increased mRNA of mitochondrial biogenesis genes, such as mitochondria transcription factor, nuclear respiratory factor 1, cytochrome c oxidase subunit 4, and ATP synthase. In HepG2 cells, eriocitrin also induced the corresponding orthologues, and reduced lipid accumulation under conditions of lipid loading. Eriocitrin increased mitochondrial size and mtDNA content, which resulted in ATP production in HepG2 cells and zebrafish [69].

Citrus medica cv Diamante peel extract lowered plasma cholesterol and triglycerides in mice [70].

The effects of Citrus aurantifolia essential oils in reducing body weight, individually and in co-administration with ketotifen, an antihistaminic drug that causes weight-gain, has been investigated using mice model. During the 45 days experimental period, the mice that received ketotifen demonstrated an enhancement both in the amount of food intake and body weight compared to the control group. Groups treated with Citrus aurantifolia essential oil displayed reduction in body weight and food consumption, possibly through promoting anorexia which might have played a role in weight loss. Interestingly, co-administration of the Citrus aurantifolia essential oil and ketotifen caused significant suppression in gaining weight, as well as decreased body weights of mice. The results suggested that Citrus aurantifolia essential oil played an important role in weight loss and could be useful in treatment of drug-induced obesity and related diseases [71].

\section{Clitoria ternatea}

The anti-hyperlipidemic effect of Clitoria ternatea L. was studied in experimentally induced hyperlipidemia in rats. The poloxamer 407-induced acute hyperlipidemia and diet-induced hyperlipidemia models were used in this investigation. Oral administration of the hydroalcoholic extract of the roots and seeds of Clitoria ternatea resulted in a significant $(p<0.05)$ reduction of serum total cholesterol, triglycerides, very low-density lipoprotein cholesterol, and low-density lipoprotein cholesterol levels. The atherogenic index and the HDL/LDL ratio were also normalized after treatment in diet-induced hyperlipidemic rats. The effects were compared with atorvastatin $(50 \mathrm{mg} / \mathrm{kg}$, po $)$ and gemfibrozil $(50 \mathrm{mg} / \mathrm{kg}$, po) [72-73].

\section{Convolvulus arvensis}

Ethanolic and aqueous extract of Convolvulus arvensis induced vasodilatation in rabbit isolated aortic rings. The molecular level $\left(\mathrm{K}^{+}\right.$and $\mathrm{Ca}^{+2}$ channels and $\alpha 1$ receptors) of vasodilator action of both ethanolic and aqueous extract of Convolvulus arvensis was studied in isolated and phenylephrine- precontracted rabbit aortic rings. The role of potassium channels was determine by using two potassium channels blockers [glibenclamide and tetraethyl ammonium (TEA)], the aortic rings were contracted by using high $\mathrm{K}^{+}$Krebs solution in order to test the role of voltage gated calcium channels (VGCC). The concentration- response curves of phenylephrine in rings were carried out before and after added the two extracts in different doses to examine the role of $\alpha 1$ receptors. The results showed that calcium-dependent $\mathrm{K}$ channels ( $\mathrm{BKCa}$ ) has a partial role in the relaxing effect of the ethanolic extract, while the $\mathrm{K}^{+}$channels did not exhibit role in case of aqueous extract. With the using of high $\mathrm{K}^{+}$Krebs, both extracts exhibited relaxant effect due to reducing the entry of calcium ions from outside. The adrenergic receptor $\alpha 1$ has a role but with different magnitude between the extracts, with high degree for aqueous extract, that reduced the maximum response $\left(\mathrm{E}_{\max }\right)$ of aortic rings to phenylephrine, and this was similar to the effect of $\alpha 1$-blocker (prazosin). Accordingly, the differences in the potency of relaxing effect gave evidence that several compounds responsible for the vasodilator effect of Convolvulus arvensis [74-76].

\section{Corchorus aestuans}

Alcoholic extract and glycosides of seeds exhibited cardiotonic activity. Corchorosid A, isolated from the plant, improved cardiac competence experimentally [77-78].

Cardiac glycoside was isolated from the plant fruits and tested for cardiotonic activity. The cardiotonic effect was studied by using isolated frog heart perfusion technique (IFHP). Ringer solution without calcium was used as a vehicle for administration of isolated cardiac glycoside as test and digoxin as standard. A significant increase in the height of force of contraction (positive inotropic effect) and decrease in heart rate (negative chronotropic effect) was observed at smaller doses $(0.4 \mathrm{mg})$. The effect increased as dose was increased. The test compound had not produced cardiac arrest even at a dose of $2 \mathrm{mg}$, compared to standard, digoxin that showed cardiac arrest at dose of $0.2 \mathrm{mg}$. Hence, as compared to standard, the tested cardiac glycoside showed wide therapeutic index [79].The anti-atherosclerotic activity of the Corchorus aestuans leaves was evaluated against Liver X alpha receptor by using GOLD study. 3-Dimensional structure of Liver X alpha receptor (Protein Date Bank ID - 3IPQ) was retrieved using Protein Data Bank. Phytochemical molecules were retrieved from the pubchem database and the 2D chemical structures were generated from SMILES notation (Simplified Molecular Input Line Entry Specification) by using the Chemsketch Software. Screenings of different docked complex were performed by GOLD study. Absorption, distribution, metabolism, excretion and toxicity properties for all molecules was predicted by using ADMET structure-activity relationship database. Among the 14 phytochemicals, E-7-Tetradecenol was found to be the top compound with highest Gold score of 26.99. 
According to the results, the authors concluded that phytochemicals from Corchorus aestuans leaves prevent atherosclerosis [80].

\section{Corchorus capsularis}

Corchortoxin (strophanthidin) was a cardiac aglycone isolated from Corchorus capsularis seeds, showed a cardio-tonic activity. These activities were similar to digitalis genus. However, jute seeds extract showed better activities than corchortoxin. Corchoroside A and B, which also isolated from other plants also showed digitalis like action [81-86].

\section{Cordia myxa}

The comparative pharmacological activity of Cordia fruit mucilage at different stages of maturity was investigated to determine the stage at which active substances were present in high proportions. The fruit mucilage of ripe and unripe Cordia myxa $(\mathrm{RCm}$ and $\mathrm{URCm})$ decreased rabbit arterial blood pressure in a dose dependent manner without affecting the respiratory rate. Mucilage from both ripe and unripe Cordia obliqua (RCo and URCo) decreased rabbit blood pressure and stimulated the respiratory rate. URCo was 12.37-fold more potent as a hypotensive agent than RCo. However the respiratory stimulant effect of RCo is 7fold more than its own hypotensive effect. Investigation of the mode of action revealed that the hypotensive effect was more likely due to activation of parasympathetic ganglia and dilatation of peripheral blood vessels, whereas the respiratory stimulant effect may partly be due to activation of chemoreceptors in the aortic arch and carotid body. In addition, a sub-effective dose of the ripe fruit mucilage specifically antagonized nicotineinduced hypotensive effect on rabbit and nicotine ganglionic stimulant effect on the isolated guinea pig ileum [87-88].

\section{Coriandrum sativum}

Coriander crude extract $(1-30 \mathrm{mg} / \mathrm{ml})$ caused fall in arterial blood pressure of anesthetized animals which partially blocked by atropine. Coriander crude extract produced vasodilatation against phenylephrine and $\mathrm{K}^{+}(80$ $\mathrm{mM}$ )-induced contractions in rabbit aorta and caused cardio-depressant effect in guinea-pig atria. Bioassaydirected fractionation revealed the separation of spasmogenic and spasmolytic components in the aqueous and organic fractions respectively. Furthermore, Coriander crude extract produced diuresis in rats at $1-10 \mathrm{mg} / \mathrm{kg}$ [89].

Aqueous extracts of coriander seeds inhibited the electrically- evoked contractions of spiral strips and tubular segments of isolated central ear artery of rabbit [90].

The water extract of coriander seed had hypotensive effects in rats [91]. The preventive effect of Coriandrum sativum (CS) on cardiac damage was evaluated by isoproterenol induced cardiotoxicity model in male rats. Rats were pretreated with methanolic extract of CS seeds at a dose of 100, 200 or $300 \mathrm{mg} / \mathrm{kg}$ orally for 30 days and they were subsequently administered (sc) with isoproterenol ( $85 \mathrm{mg} / \mathrm{kg}$ body weight) for the last two days. Isoproterenol treated rats showed increased LPO, decreased levels of endogenous antioxidants and ATPases in the cardiac tissue together with increased plasma lipids and markers of cardiac damage. TTC staining showed increased infarct areas while HXE staining showed myofibrillar hypertrophy and disruption. CS (200 and 300 $\mathrm{mg} / \mathrm{kg}$ body weight) pretreatment significantly prevented or resisted all these changes. The results showed that methanolic extract of CS is able to prevent myocardial infarction by inhibiting myofibrillar damage. It is also postulated that, the rich polyphenolic content of CS extract was responsible for preventing oxidative damage by effectively scavenging the isoproterenol generated ROS [92].

The antilipidemic activity of fresh leaves of Coriandrum sativum was studied against salbutamol induced cardiac injury in rabbits. Salbutamol administered rabbits $(50 \mathrm{mg} / \mathrm{kg})$ showed elevated level of serum lipids (LDL-cholesterol, triglyceride) and decreased level of HDL-cholesterol and antioxidant enzymes (SOD, CAT). Both the pre- and post treatment of plant extract $(100 \mathrm{mg} / \mathrm{kg})$ for three weeks exerted significant antilipidemic effect against salbutamol-induced myocardial infarction by lowering the level of serum LDL-cholesterol, triglycerides and peroxidase and increasing the level of HDL-cholesterol and antioxidant enzymes [93].

The hypolipidemic and antioxidant action of Coriandrum sativum were investigated in cholesterol-fed rabbits. Cholesterol feeding (500 mg/ kg bw/day) for 120 days caused a significant increase in serum total cholesterol, phospholipid, triglyceride, LDL-cholesterol and VLDL-cholesterol levels, whereas HDL ratio was decreased significantly when compared with control group. The changes in the antioxidant parameters were accompanied by an increase in hepatic lipid peroxidation and reduction in glutathione (GSH) and catalase activity. The level of lipid peroxidation was reduced whereas GSH content and catalase activity were elevated after the treatment with $70 \%$ methanolic extract of Coriandrum sativum at a dose of $500 \mathrm{mg} / \mathrm{kg}$ bw/day. Reduced serum lipid profile and elevated HDL ratio was observed after administration of Coriandrum sativum. Coriandrum sativum extract feeding increased the faecal excretion of cholesterol and phospholipids. Histological studies showed less cholesterol deposits in the aorta of high cholesterol diet animals given Coriandrum sativum compared to the high cholesterol diet untreated animals [94]. 
In the biphasic model of triton-induced hyperlipidemia, Coriandrum sativum at a dose of $1 \mathrm{~g} / \mathrm{kg}$ body weight reduced cholesterol and triglycerides levels in both synthesis and excretory phases in rats. The results revealed that coriander decreases the uptake and enhances the breakdown of lipids [95].

The antiperoxidative effect of coriander seeds was studied in rats administered high fat diet. Significant decrease in the levels of lipid peroxides, free fatty acids and glutathione was observed when compared to control group whereas the activity of antioxidant enzymes were increased [96].

Coriandrum sativum seeds were incorporated into diet, and the effect of the of coriander seeds on the metabolism of lipids was studied in rats fed with high fat diet and added cholesterol. The seeds had a significant hypolipidemic action. In the experimental group of rats (tissue) the level of total cholesterol and triglycerides increased significantly. There was significant increase in beta-hydroxy, beta-methyl glutaryl CoA reductase and plasma lecithin cholesterol acyl transferase activity were noted in the experimental group. The level of low density lipoprotein (LDL) and very low density lipoprotein (VLDL) cholesterol were decreased, while that of high density lipoprotein (HDL) cholesterol was increased compared to the control group [97-98].

The potential effects of dietary supplementation of coriander seed (as a lipolytic and antioxidant) was investigated on carcass lipid composition of quails. Dietary supplementation of coriander seed affected the lipid composition of carcass greatly by decreasing saturated fatty acid (SFA) contents (palmitic and stearic acids) and by increasing monounsaturated and polyunsaturated fatty acid (MUFA and PUFA) in comparison with the control group $(\mathrm{p}<0.01)$. The highest dosage of coriander seed (4\% added to the ration) systematically induced the greatest effects on fatty acid composition. Some of the acids present in coriander viz. linoleic acid, oleic acid, palmitic acid, stearic acid and ascorbic acid were very effective in reducing the cholesterol level in the blood. They also reduced the cholesterol deposition in the inner walls of the arteries and veins [99].

The efficacy of Coriandrum sativum (CS) in preventing in vitro low density lipoprotein (LDL) oxidation mediated macrophage modification was studied in rats. The efficacy of CS seed extract in alleviating pathophysiological alterations of high cholesterol diet induced atherosclerosis was also investigated in rats. High cholesterol fed atherogenic rats showed elevated lipid indices, evidences of LDL oxidation, plaque formation in thoracic aorta. The same was further validated with immune-staining of cell adhesion molecules and hematoxylin and eosin (HXE) staining. However, co-supplementation of CS to atherogenic rats recorded significant lowering these parameters, CS extract was also prevented onset and progression of atherosclerosis [100].

\section{Coronilla scorpioides}

In 1886 Cardot, announced that the Coronilla scorpioides (Medic.) Koch, was an active cardiac poison. In 1889 Schlagdenhauffen and Reeb isolated a glucoside, coronillin. The physiological studies have demonstrated that the effect of coronillin on the heart in a manner similar to digitalis. In small doses it slowed the pulse through stimulation of the inhibitory ganglia, and in larger quantity increased the tonicity and contractility of the heart, eventually leading to systolic spasm of the ventricle. This action upon the heart was accompanied by increase in the arterial pressure, followed after a time by lowering of the pressure, which apparently was the result of failure of diastole, causing the amount of blood forced out of the heart at each systole to be insufficient to fill the arteries. The drug also depressed the spinal cord, and lowered the respiratory movements by an action which was believed to be partly centric and partly peripheral. Death was produced by cardiac arrest. The dose of the commercial coronillin was commonly stated to be one and one-half grains (0.096 gm.) from four to six times a day, but it must be noted that Schlagdenhauffen mentioned that threefourths of a grain (0.048 gm.) was a toxic dose. Coronilla varia of Europe also contained coronillin [101].

\section{Coronilla varia}

The Cardiotonic and cardiotoxic effects of two cardiac glycosides, hyrcanoside and deglucohyrcanoside isolated from the seeds of Coronilla varia were evaluated in comparison with the effect and toxicity of digoxin and ouabain. Evaluation of the cardiotonic effect using the methods of heart (in situ) and the isolated heart (Langendorff) proved that deglucohyrcanoside was more effective than hyrcanoside and that its effect was equal to that of digoxin as well as ouabain. The efficacy of deglucohyrcanoside at least equal to that of digoxin, while the toxicity of the former was several times lower, which indicated that the glycoside a potential candidate for therapeutic use [102-106].

\section{Crocus sativus}

The effect of saffron was investigated against acute myocardium damage by anthracyclines compared with electrolysis as a free radical generating system. The Langendorff isolated rabbit heart model was used in this study. In one set of experiments, ROS was generated by electrolysis of the perfused heart solution ( $3 \mathrm{~mA}$ for $30 \mathrm{~min})$ in the presence and absence of saffron extracts at the optimal dose $(10 \mu \mathrm{g} / \mathrm{ml})$. In another set, the heart was perfused with anthracycline, i.e. $30 \mu \mathrm{M}$ doxorubicin (Doxo) in the presence and absence of $10 \mu \mathrm{g} / \mathrm{ml}$ saffron extracts. Cardiodynamics was evaluated in addition to biochemical and pathological parameters, to 
emphasize the effectiveness of the treatment with saffron extract using the optimal dose of catalase (150 IU) as a positive control. ROS generated, respectively, by electrolysis and by Doxo significantly $(\mathrm{p}<0.05)$ affected cardiovascular function; it decreased ventricular pressure (45.02 and 40.41\%), heart rate (36.31 and 22.39\%) and coronary flow (50.98 and $36.67 \%$ ). Increased lipid peroxidation of the myocardium was also observed (118.22 and 56.58\%), while superoxide dismutase activity decreased (48.33 and 38.70\%). The myocardial architecture was altered and the intercellular spaces increased. Saffron perfused during electrolysis helped trap ROS and significantly improved myocardial function; however, saffron was less effective against Doxo, thus suggesting that mechanisms other than oxidative stress underlie Doxo cardiotoxicity [107-108].The cardioprotective effect of Crocus sativus (saffron) aqueous extract and safranal, the major constituent of the essential oil of saffron was evaluated on lipid peroxidation, biochemical parameters and histopathological findings in isoproterenol (ISO)-induced myocardial infarction in Wistar rats. The saffron extract (20, 40, 80 and $160 \mathrm{mg} / \mathrm{kg} /$ day ip) or control were administered for 9 days along with ISO (85 mg/kg, sc at $24 \mathrm{hr}$ interval) on $8^{\text {th }}$ and $9^{\text {th }}$ day in rats. ISO administration induced a statistically significant increase $(\mathrm{p}<0.001)$ in serum activities of lactate dehydrogenase ( $\mathrm{LDH})$, creatine kinase-muscle, brain $(\mathrm{CK}-\mathrm{MB})$ and a significant increase $(\mathrm{P}<0.001)$ in the levels of thiobarbituric acid reactive substances (TBARs) in the heart as compared to vehicle control rats. Saffron pretreatment $(20,40,80$ and $160 \mathrm{mg} / \mathrm{kg}$ ip) or safranal pretreatment $(0.025,0.050,0.075 \mathrm{ml} / \mathrm{kg} \mathrm{ip})$ for 8 days, significantly decreased $(\mathrm{p}<0.001)$ the serum $\mathrm{LDH}$ and $\mathrm{CK}-\mathrm{MB}$ and myocardial lipid peroxidation as compared to ISO- induced rats. Histological findings of the heart sections confirmed myocardial injury with ISO administration and preserved nearly normal tissue architecture with saffron or safranal pretreatment [109].

The cardioprotection effect of saffron was evaluated in isoproterenol-induced myocardial damage. Male Wistar rats were divided into five groups: control, isoproterenol (ISO) and three saffron (200, 400 and 800 $\mathrm{mg} / \mathrm{kg}$ ) treatment groups. Aqueous extract of saffron or vehicle was administered orally to rats for four weeks. On days 28 and 29, the animals in ISO and saffron treatment groups were administered ISO (85 mg/kg, sc) at an interval of $24 \mathrm{~h}$. On day 30, after recording hemodynamics and left ventricular functions, animals were sacrificed for biochemical, histopathological and electromicroscopical examinations. Isoproterenol challenged animals showed depressed hemodynamics and left ventricular functions as evident by decreased left ventricular rate of peak positive and negative pressure change and elevated left ventricular end-diastolic pressure. Structural and ultrastructural studies further confirmed the damage which was reconfirmed by increased thiobarbituric acid reactive substances $(\mathrm{p}<0.001)$ and decreased creatine kinase-MB and lactate dehydrogenase $(\mathrm{p}<0.001)$. In addition, significant reduction in superoxide dismutase and catalase $(\mathrm{p}<0.001)$ was observed in ISO group. Saffron at all the doses exerted significant cardioprotective effect by preserving hemodynamics and left ventricular functions, maintaining structural integrity and augmenting antioxidant status. Among the different doses used, saffron at $400 \mathrm{mg} / \mathrm{kg}$ exhibited maximum protective effects which could be due to maintenance of the redox status of the cell which reinforcing its role as an antioxidant [110]. The effect of Crocus sativus on $\mathrm{Ca}^{2+}$ influx in isolated rat aortas was investigated by using ${ }^{45} \mathrm{Ca}$ as a radioactive tracer. $\mathrm{Ca}^{2+}$ uptake in isolated rat aorta rings in normal physiological status was not markedly altered by these drugs, whereas the $\mathrm{Ca}^{2+}$ influxes induced by norepinephrine of $1.2 \mathrm{mmol} / \mathrm{l}$ and $\mathrm{KCl}$ of $100 \mathrm{mmol} / \mathrm{l}$ were significantly inhibited by crocus in a concentration-dependent manner. The results showed that extracellular $\mathrm{Ca}^{2+}$ influx through receptor-operated $\mathrm{Ca}^{2+}$ channels and potential dependent $\mathrm{Ca}^{2+}$ channels can be blocked by crocus [111] . The effect of the hydroalcohol extract effects of Crocus sativus (saffron) was studied on (i) the basic and ratedependent electrophysiological properties of the AV node, (ii) remodeling of the AV node during experimental atrial fibrillation (AF) and (iii) the role of nitric oxide (NO) in the effects of saffron on the AV node. Stimulation protocols in isolated AV node were used to quantify AV nodal recovery, facilitation and fatigue in four groups of rabbits. In addition, the nodal response to AF was evaluated at multiple cycle lengths and during AF. Saffron had a depressant effect on AV nodal rate-dependent properties; further, it increased Wenckebach block cycle length, functional refractory period, facilitation and fatigue $(\mathrm{p}<0.05)$. NO-synthase inhibitor (LNAME) prevented the depressant effects of saffron on the AV node $(p<0.05)$. Saffron increased the zone of concealment in experimental AF $(p<0.05)$. It appeared that the depressant effects of saffron were mediated by endogenous NO [112].The effects of an aqueous-ethanol extract from Crocus sativus on heart rate and contractility were examined on isolated guinea-pig hearts. Heart rate and contractility were determined in the presence of four concentrations of the extract $(0.1,0.5,1.0$ and $5.0 \mathrm{mg} \%)$ and diltiazem $(0.1,1,10$ and 100 microm) in perfused heart with: (1) ordinary Krebs solution (group 1) and calcium-free Krebs solution (group 2). In group 1, three higher concentrations of diltiazem (1, 10 and 100 microm), but only the highest (5.0 mg\%) and two higher concentrations (1.0 and $5.0 \mathrm{mg} \%)$ of the extract caused significant reduction in heart rate and contractility, respectively ( $\mathrm{p}<0.05$ to $\mathrm{p}<0.001)$. In group 2 , the highest $(100$ microm), two higher concentrations (10 and 100 microm) of diltiazem $(\mathrm{p}<0.05$ to $\mathrm{p}<0.01)$, and the highest concentration of the extract showed significant reductions in the heart rate and contractility $(\mathrm{p}<0.05$ to $\mathrm{p}<0.01)$. There were significant negative correlations between concentrations of the extract and diltiazem and their effects in both groups ( $\mathrm{p}<0.01$ to $\mathrm{p}<0.001$ ). The results suggested a potent inhibitory effect of aqueous-ethanol extract from Crocus sativus on the calcium channel of guinea-pig heart [113]. 
The effects of Crocus sativus petals' extract on blood pressure was evaluated on anaesthetized rats. Aqueous and ethanol extracts of Crocus sativus petals reduced the blood pressure in a dose-dependent manner. Administration of $50 \mathrm{mg} / 100 \mathrm{~g}$ of aqueous extract changed the blood pressure from $133.5 \pm 3.9$ to $117 \pm 2.1$ (mmHg) [114]. The effects of saffron (Crocus sativus) stigma aqueous extract and two active constituents, crocin and safranal, were investigated on blood pressure of normotensive and desoxycorticosterone acetateinduced hypertensive rats. Three doses of crocin $(50,100$ and $200 \mathrm{mg} / \mathrm{kg})$, safranal $(0.25,0.5 \mathrm{and} 1 \mathrm{mg} / \mathrm{kg}) \mathrm{and}$ the aqueous extract $(2.5,5$ and $10 \mathrm{mg} / \mathrm{kg})$ were administered intravenously in different groups of normotensive and hypertensive animals and their effects on mean arterial blood pressure (MABP) and heart rate (HR) were evaluated. The aqueous extract of saffron stigma, safranal and crocin reduced the MABP in normotensive and hypertensive anaesthetized rats in a dose-dependent manner. Administrations of $10 \mathrm{mg} / \mathrm{kg}$ of aqueous extract, 1 $\mathrm{mg} / \mathrm{kg}$ of safranal and $200 \mathrm{mg} / \mathrm{kg}$ of crocin caused $60 \pm 8.7,50 \pm 5.2$ and $51 \pm 3.8 \mathrm{mmHg}$ reductions in MABP, respectively. Accordingly, the aqueous extract of saffron stigma had hypotensive properties which appear to be attributable, in part, to the actions of two major constitutes of this plant, crocin and safranal, and safranal was more important than crocin for lowering the blood pressure of rats [115] The effects of saffron (Crocus sativus) stigma aqueous extract was studied on blood pressure of normotensive and desoxycorticosterone acetate (DOCA)-salt induced hypertensive rats. Five weeks administration of three doses saffron aqueous extract $(10,20$ and $40 \mathrm{mg} / \mathrm{Kg} /$ day $)$ and spironolactone $(50 \mathrm{mg} / \mathrm{Kg} /$ day $)$ in different groups of normotensive and hypertensive rats (at the end of 4 weeks treatment by DOCA-salt) showed that chronic administration of saffron aqueous extract reduced the MSBP in DOCA salt treated rats in a dose dependent manner. It did not decrease the MSBP in normotensive rats. The data also showed that the antihypertensive effects of saffron did not persist [116].The influence of Crocus sativus (Saffron) aqueous extracts administration on blood pressure, pressure-rate product (PRP) and electrocardiogram (ECG) indices was studied in rat. Animals were divided to control group that orally received tap water, aqueous extracts of saffron 50, 100 and $200 \mathrm{mg} / \mathrm{kg} /$ day respectively for seven days. Different doses of saffron had no significant effect on blood pressure and PRP. Higher dose $(200 \mathrm{mg} / \mathrm{kg})$ of saffron significantly increased the PR interval, P duration, QT interval ( $\mathrm{p}<0.01)$, QRS interval, QTcn (normalized corrected QT) $(\mathrm{p}<0.001)$, and JT interval $(\mathrm{p}<0.05)$ of ECG compared to the control group. In addition, the two other doses only significantly prolonged the QT, QTen and JT intervals of ECG versus the control group. The SAF200 group also showed a notable increase in RR interval which only was significant compared to the SAF50. There was no significant difference among ST height and T amplitude ranges of different groups. Accordingly, the results revealed that high dose of saffron definitely slowed the electrical conduction velocity in both atrium and ventricle [117]. The synergic effects of saffron and electromagnetic field (EMF) on vascular endothelial growth factor receptor (VEGFR2) gene expression in MCF7 cells were investigated. MCF7 cells were grown in RPMI 1640 medium supplemented with 10\% FBS and incubated at $37^{\circ} \mathrm{C}$ with $5 \% \mathrm{CO}_{2}$. After $24 \mathrm{hr}$, cells were treated with saffron extract at concentrations of $100,200,400$ and $800 \mu \mathrm{g} / \mathrm{ml}$. Forty eight hr after treatment, all flasks were exposed with EMF $(50 \mathrm{~Hz}, 0.004$ $\mathrm{T})$. Then total RNA was extracted and cDNA was synthetized using specific primer. Synthetized products were analyzed by real time PCR to determine expression level of VEGFR2. A critical inhibitory effect on VEGFR2 gene expression wasrecorded $(20 \%)$ at $400 \mu \mathrm{g} / \mathrm{ml}$. Synergic use of EMF and saffron extract showed most reduction $(38 \%)$ at $100 \mu \mathrm{g} / \mathrm{ml}$. On the other hand synergic use of 200, 400 and $800 \mu \mathrm{g} / \mathrm{ml} \mathrm{saffron} \mathrm{aqua-}$ extract and EMF declined noticeably the VEGFR2 level of gene expression to 29, 35 and 36\%, respectively. EMF itself also reduced VEGFR2 up to $25 \%$ in comparison with control group which was remarkable at $\mathrm{p}<0.001$. Results indicated a decrease in the expression of vascular endothelial growth factor receptor in the samples treated with saffron extract compared to control. This reduction in VEGFR2 level induced by synergic treatment of saffron and EMF revealed an inhibitory effects of saffron on angiogenesis and could be also considered as a promising chemotherapeutic agent in breast cancer treatment [118].

The vasomodulatory effects of crocetin was analyzed in hypertension. Myographical experiments were performed to compare the relaxation induced by acetylcholine $(\mathrm{ACH})$ on aortic rings from normotensive (Wistar) and hypertensive (SHR) rats, incubated with or without crocetin or saffron extract and L-NAME or indomethacin. Extracts were also assayed in deendothelialized rings. Crocetin enhanced the ACH relaxations in aorta from hypertensive (strongly) and normotensive rats (weakly). Crocetin plus L-NAME abolished the relaxant response in SHR but not in Wistar aorta. Crocetin plus indomethacin did not modify the indomethacin response in either SHR or Wistar aorta. Crocetin in rubbed segments did not modify the ACH responses. In contrast, saffron increased this response in rubbed segments from SHR but not Wistar rats. Accordingly, crocetin exerts healthy vasomodulatory effects in hypertension, strongly improving endothelium-dependent $\mathrm{ACH}$ relaxations via endothelial nitric oxide but not the cyclooxygenase pathway [119]. Serum triglycerides, total-, LDL-, cholesterol, fecal excretion of fat and cholesterol were significantely inhibited by crocin (100 $\mathrm{mg} / \mathrm{kg} /$ day) compared to the control group [120]. Crocetin, was administered to rabbits to determine its effect on the development of atherosclerosis. New Zealand white rabbits were given three different diets for eight weeks: a standard diet, a high lipid diet (HLD), or a high lipid + crocetin diet. The HLD group developed hypercholesterolemia and atherosclerosis, while the crocetin-supplemented group decreased the negative health 
effects of a high lipid diet. However, the results did not show a significant difference in the plasma lipid levels (total, low density lipoprotein (LDL), and high density lipoprotein (HDL) cholesterol) between the HLD and crocetin groups but showed significant decrease in the aorta cholesterol deposits, atheroma, foam cells, and atherosclerotic lesions. The authors suggested that nuclear factor kappa B (NF- $\mathrm{B})$ activation in the aorta was suppressed by crocetin which in turn decreased the vascular cell adhesion molecule-1 (VCAM-1) expression [121].

Administration of a monthly intramuscular injection of crocetin reduced serum cholesterol concentrations by $50 \%$, and the severity of atherosclerosis by $30 \%$ in rabbits fed an atherosclerosis-inducing diet [122]. Crocin exerted antiatherosclerotic effects through decreasing the level of Ox-LDL that plays an important role in the initiation and progression of atherosclerosis [123]. Fifty milligrams of saffron dissolved in $100 \mathrm{ml}$ of milk was administered twice a day to human subjects, the significant decrease in lipoprotein oxidation susceptibility in patients with coronary artery disease (CAD) indicated the potential of saffron as an antioxidant [124]. A hot aqueous extract 10-100 $\mathrm{mg} / \mathrm{ml}$, prolonged partial thromboplastin and prothrombin times, and inhibited platelet aggregation in human platelets induced by adenosine diphosphate and collagen in vitro [125].The inhibitory activity of saffron extract was studied on human platelets. Platelet aggregation and lipid peroxidation were evaluated with platelet rich plasma (PRP) and platelet membranes obtained from blood of healthy human volunteers. Human platelets were subjected to stimulation with a variety of agonists like ADP (61 microM), epinephrine (76 microM), collagen (11 microg/ml), calcium ionophore A 23187 (6 microM) and ristocetin $(1.25 \mathrm{microg} / \mathrm{ml})$ in the presence and absence of saffron extract. The inhibitory effect was dose dependent with concentrations varying between 0.16 to $0.80 \mathrm{mg}$ and time dependent. A significant decrease was observed in malondialdehyde (MDA) formed, one of the end products of arachidonic acid metabolism and of serotonin released from dense granules of platelets at respective $\mathrm{IC}_{50}$. Lipid peroxidation in platelet membranes induced by iron-ascorbic acid system was inhibited by saffron extract significantly with $\mathrm{IC}_{50}$ of $0.33 \mathrm{mg}$. Hence, it may be said that aqueous extract of saffron may have component(s), which protect platelets from aggregation and lipid peroxidation [126].Healthy, mildly overweight women $(\mathrm{N}=60)$ participated in a randomized, placebo-controlled, double-blind study to evaluated the efficacy of satiereal supplementation (Inoreal Ltd, Plerin, France), a novel extract of saffron stigma, on body weight changes over an 8-week period. They took twice capsule of satiereal (176.5 mg extract per day or a matching placebo. Caloric intake was left unrestricted during the study. At baseline, both groups were homogeneous for age, body weight, and snacking frequency. Satiereal caused a significantly greater body weight reduction than placebo after 8 weeks $(\mathrm{p}<0.01)$. The mean snacking frequency was significantly decreased in the satiereal group as compared with the placebo group $(\mathrm{P}<.05)$. Other anthropometric dimensions and vital signs remained almost unchanged in both groups. No subject withdrawal attributable to a product effect was reported throughout the trial, suggesting a good tolerability to satiereal [127].

\section{Crotalaria juncea}

The antihypercholesterolemic effects of 50 and $100 \mathrm{mg} / \mathrm{kg}$ bw per day of an ethanolic extract of Crotalaria juncea Linn (whole plant) were investigated in rats fed high-fat diet by evaluating food consumption, weight gain, fecal fat excretion, serum and liver lipids, and biochemical profiles as well as by histopathological studies. The results were compared to animals fed with the standard diet and animals fed with a high-fat diet and atorvastatin $(10 \mathrm{mg} / \mathrm{kg} \mathrm{bw})$. The animal group administered with the ethanolic extract for 35 days showed decreased levels of TC, LDL, VLDL, TG, HDL+VLDL, VLDL+LDL, LDL/TC, AI, SGOT, SGPT, and elevated levels of HDL, HDL/TC, significantly $(p<0.01$ and $p<0.05)$ in a dose-dependent manner.

The evaluation of liver tissues of the animal groups treated with the herbal extract and standard, showed increased levels of SOD, GSH, and catalase, whereas levels of SGOT, SGPT, total glucose, HMG-CoA, lipase, amylase, and the percentage of malon-dialdehyde were decreased when compared with the high-fat-diet fed rats. Body weight and food intake in the treated groups were significantly lower than that in the control [128-129].

The antihyperlipidemic activity of alcoholic and methanol extract of leaves of Crotolaria juncea (CJ) was investigated against Triton induced hyperlipidemia in mice. CJ was administered at a dose of 100 and $200 \mathrm{mg} / \mathrm{kg}$ (po) to Triton induced hyperlipidemic mice. Atorvastatin was used as reference standard. CJ showed a significant decrease in the levels of serum total cholesterol, triglyceride, LDL, VLDL and significant increase in the level of serum HDL at the dose of 100 and $200 \mathrm{mg} / \mathrm{kg}$ (po) against Triton induced hyperlipidemia in mice [130].

The unusual amino acid, 2-amino-5-hydroxyhexanoic acid isolated from the seeds of Crotalaria juncea, showed dose dependent lipid lowering activity in the in vivo experiments and also showed good in vitro antioxidant activity. The cyclized compound, 3-amino-6-methyltetrahydro-2H-pyran-2-one showed better lipid lowering and antioxidant profile than the parent compound [131]. 
Anti-obesity effect of Crotalaria juncea leaves extract was documented in high fat induced obesity in rats [132].

\section{Cuminum cyminum}

Extract of cumin inhibited arachidonate-induced platelet aggregation. It also inhibited thromboxane B2 production from exogenous $\left({ }^{14} \mathrm{C}\right)$ arachidonic acid (AA) in washed platelets, in addition, a simultaneous increase in the formation of lipoxygenase-derived products was also observed [133-134].

The anti-hypertensive potential of standardized aqueous extract of Cuminum cyminum seeds and its role in arterial endothelial nitric oxide synthase expression, inflammation, and oxidative stress were evaluated in renal hypertensive rats. Renal hypertension was induced by the two-kidney one-clip (2K/1C) method in rats. Systolic blood pressure (SBP), plasma nitrate/nitrite, carotid-eNOS, renal-TNF- $\alpha$, IL-6, Bax, Bcl-2, thioredoxin 1 (TRX1), and thioredoxin reductase 1 (TRXR1) mRNA expressions were studied to demonstrate the antihypertensive action of Cuminum cyminum. Cuminum cyminum seed was administered orally $(200 \mathrm{mg} / \mathrm{kg} \mathrm{bw})$ for a period of 9 weeks, it improved plasma nitric oxide and decreased the systolic blood pressure in hypertensive rats. It also up-regulated the gene expression of eNOS, Bcl-2, TRX1, and TRXR1; and downregulated Bax, TNF- $\alpha$, and IL- 6 . The data revealed that Cuminum cyminum seeds augment endothelial functions and ameliorate inflammatory and oxidative stress in hypertensive rats [135]. The hypocholesterolemic effect of methanolic extract of Cuminum cyminum (MCC) was evaluated in ovariectomized (OVX) rats. MCC 1000 $\mathrm{mg} / \mathrm{kg}$ and estradiol benzoate equivalent to $0.15 \mathrm{mg} / \mathrm{kg}$ of estradiol were administered to OVX rats per orally for 10 weeks. The results indicated that estradiol as well as MCC protected OVX rats against increased cholesterol levels due to ovariectomy, MCC was better than estradiol [136].The effect of cumin powder on body composition and lipid profile was studied in overweight and obese women in a randomized clinical trial. 88 overweight/obese women were randomly assigned into two groups. The experimental group was given $3 \mathrm{~g} /$ day cumin powder with yogurt at two meals for 3 months. The same amount of yogurt without cumin powder was prescribed for the control group. All patients received nutrition counseling for weight loss in a similar manner. Anthropometric and biochemical parameters were determined before and after the intervention. Cumin powder reduced serum levels of fasting cholesterol, triglyceride, and LDL and increased HDL. Weight, BMI, waist circumference, and fat mass were also significantly reduced. However, it exerted no effect on FBS and fat-free mass [137]. The effects of cumin extract supplementation on oxLDL, paraoxanase 1 activity, FBS, total cholesterol, triglycerides, High density lipoprotein cholesterol (HDL-C), low density lipoprotein cholesterol (LDL-C), apolipoprotein A1 (Apo A1), and apolipoprotein B (Apo B) were studied in the patients with hypercholesterolemia. The results demonstrated that there was a significant decrease in the level of oxLDL after receiving cumin. Paraoxonase and arylesterase activities increased in serum after taking cumin extract. Paraoxanase 1 (PON1) played a protective role against the oxidative modification of plasma lipoproteins and hydrolyzes lipid peroxides in human atherosclerotic lesions [138] The effects of Cuminum cyminum intake on weight loss and metabolic profiles among overweight subjects was studied by a randomized double-blind placebo-controlled clinical trial which conducted among 78 overweight subjects (male, $\mathrm{n}=18$; female, $\mathrm{n}=60$ ) aged 18-60 years old. Participants were randomly assigned into three groups to receive: (1) Cuminum cyminum capsule $(n=26)$; (2) orlistat 120 capsule $(n=26)$ and (3) placebo $(n=26)$ three times a day for 8 weeks. Anthropometric measures and fasting blood samples were taken at baseline and after 8 weeks of intervention. Consumption of the Cuminum cyminum and orlistat120 resulted in a similar significant decrease in weight $(-1.1$ \pm 1.2 and $-0.9 \pm 1.5$ compared with placebo $0.2 \pm 1.5 \mathrm{~kg}$, respectively, $\mathrm{p}=0.002)$ and BMI $(-0.4 \pm 0.5$ and -0.4 \pm 0.6 compared with placebo $0.1 \pm 0.6 \mathrm{~kg} / \mathrm{m}(2)$, respectively, $\mathrm{p}=0.003)$. In addition, Cuminum cyminum L., compared with orlistat and placebo, led to a significant reduction in serum insulin levels $(-1.4 \pm 4.5$ vs. $1.3 \pm 3.3$ and $0.3 \pm 2.2 \mu \mathrm{IU} / \mathrm{ml}$, respectively, $\mathrm{p}=0.02)$, HOMA-B $(-5.4 \pm 18.9$ vs. $5.8 \pm 13.3$ and $1.0 \pm 11.0$, respectively, $\mathrm{p}=0.02)$ and a significant rise in QUICKI $(0.01 \pm 0.01$ vs. $-0.005 \pm 0.01$ and $-0.004 \pm 0.01$, respectively, $\mathrm{p}=$ 0.02) [139].

\section{Cupressus sempervirens}

The effects of Cupressus sempervirens cone extract (CSE) on the lipid profile was studied in Wistar rats. The oral administration of the extract resulted in a substantial decrease of serum total cholesterol, which was significant even after 6 weeks of treatment. Moreover, these animals exhibited lower total cholesterol levels compared to the controls after the initiation of treatment $(\mathrm{p}<0.001)$. The administration of the extract also led to a substantial reduction in serum triglycerides $(\mathrm{p}<0.05)$, comparing 0 week to 6-24 weeks. However no significant differences in triglyceride levels were observed between CSE animals and controls during the entire study period. No significant changes in HDL-cholesterol level [140-141]. In vitro assessment of endothelial cell function in isolated aortic rings of rats pretreated with Cupressus cones water extract showed increased production of endothelium-derived nitric oxide. Additionally, it possessed anticoagulant properties. Based on these effects, its effect on survival of random extensions of ischemic axial flaps was investigated. The pretreated group received $30 \%$ of cypress cones water extract treatment orally 7 days before flap elevation and 
for 3 days afterward. The ischemic target was a $6 \times 7 \mathrm{~cm}$ islanded epigastric artery flap based on the right inferior epigastric pedicle. After the observation period, hemodynamic variables including mean arterial pressure and heart rate were assessed. Flap survival and perfusion rates were determined by microangiography and laser doppler flowmetry. In vitro isometric tension of the aortic segments isolated from the control and pretreated groups was monitored to reflect vascular responsiveness. The dose response relations to acetylcholine was determined and compared with control group. There were no significant differences between the hemodynamic variables. In the pretreated group, microangiograms revealed increased angiogenesis and capillary density and enhanced flap perfusion (as blood perfusion units) in the right distal and proximal parts $(\mathrm{p}<0.05)$. Endothelium-derived nitric oxide - dependent maximal relaxation $\left(\mathrm{E}_{\max }\right)$ and the $\mathrm{EC}_{50}$ value to acetylcholine were significantly greater in the pretreated group compared to that of the controls. Accordingly, the data suggest that pretreatment with cypress water extract enhances the viability of ischemically challenged flaps [142].

\section{Cydonia oblonga}

The effect of ethanol leaf extracts of Cydonia oblonga Mill. (COM) was studied on hypertension and on biomarkers associated with blood pressure control, such as angiotensin-II (AII), plasma renin activity (PRA), apelin-12 (A), endothelin (ET) and nitric oxide (NO), compared to captopril. Two-kidney one-clip (2K1C) Goldblatt model rats were divided randomly into six groups: sham, model, captopril $25 \mathrm{mg} / \mathrm{kg}$, COM leaf extract 80, 160 and $320 \mathrm{mg} / \mathrm{kg}$. Drugs were administered orally daily for eight weeks. Systolic blood pressure (SBP) and diastolic blood pressure (DBP) were measured before treatment and every 2 weeks. Blood and kidney samples were collected after the last treatment to measure AII, PRA, A, ET and NO. Renal hypertensive rats (RHR) had increased blood pressure, AII, A, PRA, ET and decreased NO. Treatment with captopril reduced blood pressure, AII, A, PRA, and ET, though not quite to normal values. COM leaf extracts significantly and dose-dependently reduced blood pressure, AII, A, RA and ET, whereas NO was increased. The effects of COM extracts on blood pressure and biomarkers were dose-dependent and at the highest dose, it produced effects similar to those of captopril [143-144].The effects of Cydonia oblonga. (COM) fruit and leaf extracts on blood pressure and rheology were studied in renal hypertensive rats (RHR). Daily doses of 80 and $160 \mathrm{mg} / \mathrm{kg}$ aqueous or ethanol extracts of COM fruit or leaves, or $25 \mathrm{mg} / \mathrm{kg}$ captopril were given orally once daily for 8 weeks. Blood pressure was measured before treatment and every 2 weeks thereafter. Blood rheology was tested after 8 weeks. Model rats had higher blood pressure than sham, 8 weeks after the procedure (systolic blood pressure $193 \pm 7$ vs. $138 \pm 8 \mathrm{mmHg}$, p <0.05). Those treated with captopril had decreased blood pressure within 2 weeks but that did not return to the level found in the sham group at 8 weeks $(167 \pm 7, \mathrm{p}<0.05$ vs. model). With the COM extracts, the effect on blood pressure was notable after 4 weeks. At 8 weeks blood pressure was similar with captopril and with $160 \mathrm{mg}$ ethanol leaf extract $(166 \pm 4$, p $<0.05$ vs. model), it was the most effective of the extracts. Model rats had higher blood viscosity and lower erythrocyte deformability than sham. Captopril had little effect on blood rheology; whereas COM extracts reduced whole blood viscosity and improved erythrocyte deformability to levels approaching those found in sham [145]. The hypolipidemic effect of Cydonia oblonga was studied in a rat model. low-, medium- and high-dose Cydonia oblonga leaf extracts (COM) were given orally for 56 days. The normal controls were fed a normal diet, all other groups a high fat diet. COM dosedependently reduced TC, TG, LDL-C and MDA, inhibited the activity of ALT, AST and LPS, increased HDL$\mathrm{C}$ content, increased the activity of SOD, GSH-PX, LPL and HL, and reduced liver steatosis in hyperlipidaemia rats, significant at medium and high doses. The effect of COM was similar to that of simvastatin except for increased lipoprotein lipase and hepatic lipase which were reduced by COM but not by simvastatin [146].

The effects of Cydonia oblonga Miller (COM) total flavonoids (TF) from leaves and fruit on the blood lipid and antioxidant potentials were studied using hyperlipidaemic rat models. Compared with the hyperlipidaemic model group, TF significantly reduced serum TC, TG, LDL-C $(\mathrm{p}<0.01)$, ALT and AST $(\mathrm{p}<0.01$ or $\mathrm{p}<0.05)$ and increased HDL-C $(p<0.05$ or $p<0.01)$. TF also reduced MDA $(p<0.01$ or $p<0.01)$ [147]. The effects of hydromethanolic extract of quince leaf was investigated on the lipid profile of rabbits fed with cholestrol enriched diet $(2 \% \mathrm{w} / \mathrm{w}$ for two months). Animals were treated as follow: no treatment (NT), atrovastatin (AT) $(0.5 \mathrm{mg} / \mathrm{kg} / \mathrm{day})$ and quince extract (QE) (dried extract, $50 \mathrm{mg} / \mathrm{kg} / \mathrm{day}$ ) treatment, and then fed with normal diet for three months. Significant increases $(\mathrm{p}<0.05)$ in the mean values of cholestrol I, triglyceride, low density lipoprotein, aspartate aminotransferase, alanine transaminase, creatinine, and alkaline phosphatase with a significant decrease $(\mathrm{p}<0.05)$ in high density lipoprotein level, were recorded after receiving cholestrol enriched diet in comparison with the control group [148]. The effects of Cydonia oblonga Miller (COM) extracts was investigated on models and markers of thrombosis and related biomarkers in mice. 20, 40, $80 \mathrm{mg} / \mathrm{kg} / \mathrm{day} \mathrm{COM}$ aqueous extracts or $5 \mathrm{mg} / \mathrm{kg} /$ day aspirin, were given orally for 14 days and were compared to untreated controls regarding bleeding and clotting times, using the tail cutting and glass slide methods and for death rates in collagen-epinephrine pulmonary thrombosis, thrombolysis in vitro and euglobulin lysis time (ELT). Common carotid artery $\mathrm{FeCl}_{3}$-induced thrombus and inferior vena cava thrombosis occlusion time, plasma concentrations of thromboxane B2 (TXB2) and 6-keto-prostaglandine F1 $\alpha$ (6-keto-PGF1 $\alpha$ ) were measured. Compared to 
controls, COM extracts dose-dependently prolonged bleeding by 2.17, 2.78 and 3.63 times, compared with aspirin 2.58, and the clotting time by $1.44,2.47$ and 2.48 times, compared with aspirin 1.91. COM reduced pulmonary embolus mortality by 27, 40 and 53\%, compared with $47 \%$ for aspirin. COM dose-dependently increased thrombolysis by 45,55 and $63 \%$, compared with $56 \%$ for aspirin, and shortened ELT to 71, 61 and $43 \%$, compared with $43 \%$ for aspirin. In rats, venous occlusion time was prolonged. Arterial and venous thrombus weights were dose-dependently reduced in COM groups. TXB2 decreased and 6-keto-PGF1 $\alpha$ increased with COM and aspirin, with an association between 6 -keto-PGF1 $\alpha / \mathrm{TXB} 2$ and arterial or venous thrombus weight for all products, and for occlusion time with COM but not for aspirin [149].

\section{Cynodon dactylon}

Cynodon dactylon caused rise in heart beat rate in zebra fish embryos significantly higher than that caused by betamethosone. The $\mathrm{EC}_{50}$ value of Cynodon dactylon was found to be $3.738 \mu \mathrm{g} / \mathrm{ml}$ [150].

The effects of hydroalcoholic extract of Cynodon dactylon rhizomes was evaluated on cardiac contractility in normal hearts and on cardiac functions in right-heart failure in rats. Right-heart failure was induced by intraperitoneal injection of monocrotaline $(50 \mathrm{mg} / \mathrm{kg})$. Two weeks later, the animals were treated orally with different doses of the extract for fifteen days. At the end of the experiments, cardiac functions and markers of myocardial hypertrophy were measured. The treated rats showed very less signs of fatigue, peripheral cyanosis and dyspnea. The survival rate was high in the extract treated groups (90\%). Administration of Cynodon dactylon in monocrotaline-injected rats led to profound improvement in cardiac functions as demonstrated by decreased right ventricular end diastolic pressure (RVEDP) and elevated mean arterial pressure. RVdP/dtmax, and $\mathrm{RVdP} / \mathrm{dt} / \mathrm{P}$ as indices of myocardial contractility were also markedly $(\mathrm{p}<0.001)$ increased by the extract. The extract reduced heart and lung congestion by decreasing tissue wet/dry and wet/body weight ratios $(\mathrm{p}<0.01)$. In the isolated rat hearts, the extract produced a remarkable $(\mathrm{p}<0.001)$ positive inotropic effect concomitant with a parallel decrease in LVEDP [151].The phenolic fraction of Cynodon dactylon (CDP) was evaluated for its cardio-protective activity using isolated frog's heart perfusion method. The CDP produced negative inotropic and chronotropic actions on isolated frog heart. These pharmacological effect were selectively inhibited by atropine, which indicated that these effects were mediated through muscarinic receptor [152].The probable antiarrhythmic effects of Cynodon dactylon against ischemia/ reperfusion (I/R)-induced arrhythmias were investigated in isolated rat heart. The hearts were subjected to 30min regional ischemia followed by 30min reperfusion and perfused with hydroalcoholic extract of rhizome of Cynodon dactylon (25, 50,100 and $200 \mu \mathrm{g} / \mathrm{ml}$ ). During ischemia, the extract produced marked reduction in the number, duration and incidences of ventricular tachycardia (VT) at 25 and $50 \mu \mathrm{g} / \mathrm{ml}(\mathrm{p}<0.001$ and $\mathrm{p}<0.01)$ respectively. Total number

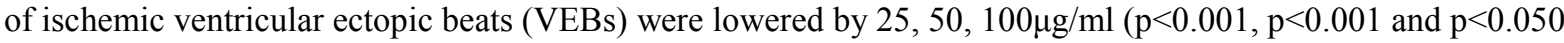
respectively. At the reperfusion phase, Cynodon dactylon $(25$ and $50 \mu \mathrm{g} / \mathrm{ml})$ decreased incidence of VT from $100 \%$ (control) to 13 and $33 \%(\mathrm{p}<0.001$ and $\mathrm{p}<0.05)$ respectively. Duration and number of VT and total VF incidence were also reduced at the same concentration $(\mathrm{p}<0.05$ for all). Perfusion of the extract $(25,50$, $100 \mu \mathrm{g} / \mathrm{ml}$ ) was markedly lowered reversible VF duration from $218 \pm 99$ second to 0 second, 0 second and $10 \pm 5$ second ( $\mathrm{p}<0.01, \mathrm{p}<0.01$ and $\mathrm{p}<0.05)$ respectively. Moreover, Cynodon dactylon $(25$ and $50 \mu \mathrm{g} / \mathrm{ml})$ decreased number of total VEBs from $349 \pm 73$ to $35 \pm 17(\mathrm{p}<0.001)$ and $66 \pm 26(\mathrm{p}<0.01)$. it was also shown that perfusion of the extract produced a marked and concentration-dependent positive inotropic effect [153].

The haemostatic activity of Cynodon dactylon was studied in albino rats. The Bleeding Time (BT) in control group was $160.5 \pm 8.3$ second and in test group $96.8 \pm 10.3$ second. The Clotting Time (CT) in control group was $507.6 \pm 18.2$ second and in test group 319.3 \pm 27.1 second [154-155].

\section{Cyperus rotuntdus}

Hypolipidaemic activity of Cyperus rotundus rhizomes was evaluated in high fat diet induced hyperlipidaemic rats $(70,140$ and $280 \mathrm{mg} / \mathrm{kg} \mathrm{bw})$. The results demonstrated statically significant reduction in serum lipid profile. Treatment with different doses of extract exerted statistically significant $(\mathrm{p}<0.05)$ reduction in serum total cholesterol, LDL, TG levels at the end of 15 days of intervention [156-157].

The preventive role of ethanolic extract of Cyperus rotundus rhizomes (CRRE) was investigated on age associated changes in glucose and lipids in young and aged rats. CRRE was given as $(500 \mathrm{mg} / \mathrm{kg}$ body weight) orally for 30 days. Age associated increase in serum glucose, total cholesterol, triglycerides, LDL cholesterol, VLDL cholesterol and a decrease in HDL cholesterol was observed in aged rats compared to young rats. Administration of CRRE to aged rats prevented the age associated changes in glucose, total cholesterol, triglycerides, LDL cholesterol and VLDL cholesterol. HDL cholesterol level was found to be increased significantly in both young and aged rats after treatment with CRRE [158].

The biological efficacy of Cyperus rotundus tubers extract was studied on weight control in obese Zucker rats. Administration of 45 or $220 \mathrm{mg} / \mathrm{kg} / \mathrm{day}$ of Cyperus rotundus tubers hexane extract for 60 days in Zucker rats induced a significant reduction in weight gain without affecting food consumption or inducing toxicity. In vitro, $250 \mathrm{microg} / \mathrm{ml}$ of this extract was able to stimulate lipolysis in 3T3-F442 adipocytes 
suggesting that this medicinal plant contained activators of beta-adrenoreceptors (AR). The binding assay performed on the rat beta3-AR isoform, known to induce thermogenesis, demonstrated that Cyperus rotundus tubers extract can consistently and effectively bind to this receptor. The data suggest that the effect on weight gain exerted by Cyperus rotundus tubers extract may be mediated, at least partially, through the activation of the beta3-AR [159].

The antiplatelet activities of Cyperus rotundus ethanolic extract (CRE) and eight of its constituent compounds were evaluated by examining their effects on rat platelet aggregations in vitro and ex vivo, and on mice tail bleeding times. During the in vitro platelet aggregation study, CRE showed significant and concentration dependent inhibitory effects on collagen-, thrombin-, and/or arachidonic acid (AA)-induced platelet aggregation. Of its eight components, (+)-nootkatone was found to have the most potent inhibitory effect on collagen-, thrombin-, and AA-induced platelet aggregation. In addition, CRE- and (+)-nootkatone-treated mice exhibited significantly prolonged bleeding times. Furthermore, (+)-nootkatone had a significant inhibitory effect on rat platelet aggregation ex vivo [160]. In studying the effect of Cyperus rotundus on the hemorrheological changes in normal rats, Cyperus rotundus can improve all hemorrheological indexes, such as the whole blood specific viscosity, the plasma specific viscosity, erythrocyte electrophoresis, etc [161].

\section{CONCLUSION}

This review highlights the cardiac, cardioprotective, vascular, hypolipidemic, fibrinolytic and anti platelet aggregating of medicinal plants as promising drugs as a result of effectiveness and safety.

\section{REFERENCES}

[1] Al-Snafi AE. Therapeutic properties of medicinal plants: a review of plants with cardiovascular effects (part 1). Int J of Pharmacology \& Toxicology 2015; 5(3): 163-176.

[2] Al-Snafi AE. Therapeutic properties of medicinal plants: a review of plants with hypolipidemic, hemostatic, fibrinolytic and anticoagulant effects (part 1). Asian Journal of Pharmaceutical Science \& Technology 2015; 5(4): 271-284.

[3] Al-Snafi AE. Chemical constituents and pharmacological activities of Milfoil (Achillea santolina) - A Review. Int J Pharm Tech Res 2013, 5(3): 1373-1377.

[4] Al-Snafi AE. Adonis aestivalis: pharmacological and toxicological activities- A revew. Asian Journal of Pharmaceutical Science \& Technology 2016; 6(2): 96-102.

[5] Al-Snafi AE. The pharmacological and therapeutic importance of Agrimonia eupatoria- A review. Asian Journal of Pharmaceutical Science and Technology 2015; 5(2): 112-117.

[6] Al-Snafi AE. Chemical constituents and pharmacological importance of Agropyron repens - A review. Research Journal of Pharmacology and Toxicology 2015; 1 (2): 37-41.

[7] Al-Snafi AE. Alhagi maurorum as a potential medicinal herb: An Overview. International Journal of Pharmacy Review and Research 2015; 5(2):130-136.

[8] Al-Snafi AE. Pharmacological effects of Allium species grown in Iraq. An overview. International Journal of Pharmaceutical and health care Research 2013;1(4):132-147.

[9] Al-Snafi AE. The pharmacological importance of Aloe vera- A review. International Journal of Phytopharmacy Research 2015; 6(1) : 28-33.

[10] Al-Snafi AE. The pharmacological activities of Alpinia galangal - A review. International Journal for Pharmaceutical Research Scholars 2014; 3(1-1): 607-614.

[11] Al-Snafi AE. The Pharmaceutical importance of Althaea officinalis and Althaea rosea: A Review. Int J Pharm Tech Res 2013; 5(3):1387-1385.

[12] Al-Snafi AE. Chemical constituents and pharmacological activities of Ammi majus and Ammi visnaga. A review. International Journal of Pharmacy and Industrial Research 2013; 3(3):257-265.

[13] Al-Snafi AE. The pharmacology of Anchusa italica and Anchusa strigosa - A review. International Journal of Pharmacy and Pharmaceutical Sciences 2014; 6(4): 7-10.

[14] Al-Snafi AE. The pharmacological importance of Anethum graveolens - A review. International Journal of Pharmacy and Pharmaceutical Sciences 2014; 6(4): 11-13.

[15] Al-Snafi AE. Medical importance of Antemis nobilis ( Chamaemelum nobilis)- A eview. Asian Journal of Pharmaceutical Science \& Technology 2016; 6(2): 89-95.

[16] Al-Snafi AE. The Pharmacology of Apium graveolens. - A review. International Journal for Pharmaceutical Research Scholars 2014; 3(1-1): 671-677.

[17] Al-Snafi AE. Chemical constituents and pharmacological activities of Arachis hypogaea. - A review. International Journal for Pharmaceutical Research Scholars 2014; 3(1-1): 615-623.

[18] Al- Snafi, AE. The best lysosomal stabilizing and hypolipoproteinemic mono/ polyunsaturated fatty acids combination . Med. J . Tikrit Univ 2002; 8:148-153. 
[19] Al-Snafi AE. Encyclopedia of the constituents and pharmacological effects of Iraqi medicinal plants. Thi qar University, 2013

[20] Al-Snafi AE. Chemical constituents and pharmacological effects of Asclepias curassavica - A review. Asian Journal of Pharmaceutical Research 2015; 5(2): 83-87.

[21] Al-Snafi AE. The pharmacological importance of Asparagus officinalis - A review. Journal of Pharmaceutical Biology 2015; 5(2): 93-98.

[22] Al-Snafi AE. The nutritional and therapeutic importance of Avena sativa - An Overview. International Journal of Phytotherapy 2015; 5(1): 48-56.

[23] Al-Snafi AE. The pharmacology of Bacopa monniera. A review. International Journal of Pharma Sciences and Research 2013; 4(12): 154-159.

[24] Al-Snafi AE. The Pharmacological importance of Bauhinia variegata. A Review. International Journal of Pharma Sciences and Research 2013; 4(12): 160-164.

[25] Al-Snafi AE. The Pharmacological importance of Bellis perennis - A review. International Journal of Phytotherapy 2015; 5(2): 63-69.

[26] Al-Snafi AE. The Pharmacological Importance of Benincasa hispida. A review. Int Journal of Pharma Sciences and Research 2013; 4(12): 165-170.

[27] Al-Snafi AE. The pharmacological importance of Brassica nigra and Brassica rapa grown in Iraq. J of Pharm Biology 2015; 5(4): 240-253.

[28] Al-Snafi AE. The Chemical constituents and pharmacological effects of Bryophyllum calycinum. A review. Journal of Pharma Sciences and Research 2013; 4(12): 171-176.

[29] Al-Snafi AE. Pharmacology and medicinal properties of Caesalpinia crista - An overview. International Journal of Pharmacy 2015; 5(2): 71-83.

[30] Al-Snafi AE. Encyclopedia of the constituents and pharmacological effects of Iraqi medicinal plants. Thi qar University, 2013

[31] Al-Snafi AE. The chemical constituents and pharmacological effects of Calendula officinalis - A review. Indian Journal of Pharmaceutical Science \& Research 2015; 5(3): 172-185.

[32] Al-Snafi AE. The constituents and pharmacological properties of Calotropis procera - An Overview. International Journal of Pharmacy Review \& Research 2015; 5(3): 259-275.

[33] Al-Snafi AE. The chemical constituents and pharmacological effects of Capparis spinosa - An overview. Indian Journal of Pharmaceutical Science and Research 2015; 5(2): 93-100.

[34] Al-Snafi AE. The pharmacological importance of Capsicum species (Capsicum annuum and Capsicum frutescens) grown in Iraq. Journal of Pharmaceutical Biology 2015; 5(3): 124-142.

[35] Al-Snafi AE. Cardiovascular effects of Carthamus tinctorius: A mini-review. Asian Journal of Pharmaceutical Research 2015; 5(3): 199-209.

[36] Al-Snafi AE. The chemical constituents and pharmacological importance of Carthamus tinctorius - An overview. Journal of Pharmaceutical Biology 2015; 5(3): 143-166.

[37] Al-Snafi AE. The chemical constituents and pharmacological effects of Carum carvi - A review. Indian Journal of Pharmaceutical Science and Research 2015; 5(2): 72-82.

[38] Al-Snafi AE. The pharmacological importance of Casuarina equisetifolia - An Overview. International Journal of Pharmacological Screening Methods 2015; 5(1): 4-9.

[39] Al-Snafi AE. The chemical constituents and pharmacological importance of Celosia cristata - A review. J of Pharm Biology 2015; 5(4): 254-261.

[40] Al-Snafi AE. The pharmacological importance of Centaurea cyanus- A review. Int J of Pharm Rev \& Res 2015; 5(4): 379-384.

[41] Pedroche J, Vioque J, Millan F, Alaiz M, Gir J and Yust MM. Production of ACE inhibitory peptides by digestion of chickpea legumin with alcalase. Food Chemistry 2003; 81: 363-369.

[42] Al-Snafi AE. The medical Importance of Cicer arietinum - A review IOSR Journal of Pharmacy 2016; 6(3): 29-40.

[43] Yust Mdel M, Millán-Linares Mdel C, Alcaide-Hidalgo JM, Millán F and Pedroche J. Hypocholesterolaemic and antioxidant activities of chickpea (Cicer arietinum L.) protein hydrolysates. J Sci Food Agric 2012; 92(9):1994-2001.

[44] Balbaa SI, Zaki AY, Abdel-Wahab SM, El-Denshary ESM and Motazz-Bellah M. Preliminary phytochemical and pharmacological investigations of the roots of different varieties of Cichorium intybus. Planta Med 1973; 24(6): 133-144.

[45] Al-Snafi AE. Medical importance of Cichorium intybus - A review IOSR Journal of Pharmacy 2016; 6(3): 41-56.

[46] 46-Sakurai N, Iizuka T, Nakayama S, Funayama H, Noguchi M and Nagai M. Vasorelaxant activity of caffeic acid derivatives from Cichorium intybus and Equisetum arvense. Yakugaku Zasshi 2003;123(7):593-598. 
[47] 47-Noori S and Mahboob T. Role of electrolytes disturbances and $\mathrm{Na}^{+}-\mathrm{K}^{+}$-ATPase in cisplatin - induced renal toxicity and effects of ethanolic extract of Cichorium intybus. Pak J Pharm Sci 2012;25(4):857-862.

[48] Schumacher E, Vigh E, Molnár V, Kenyeres P, Fehér G, Késmárky G, Tóth K and Garai J. Thrombosis preventive potential of chicory coffee consumption: a clinical study. Phytother Res. 2011; 25(5):744-748.

[49] Shimoda H, Tanaka J, Takahara Y, Takemoto K, Shan SJ and Su MH. The hypocholesterolemic effects of Cistanche tubulosa extract, a Chinese traditional crude medicine, in mice. Am J Chin Med 2009;37(6):1125-1138.

[50] He WJ, Fang TH, Ma X, Zhang K, Ma ZZ and Tu PF. Echinacoside elicits endothelium-dependent relaxation in rat aortic rings via an NO-cGMP pathway. Planta Med 2009; 75(13):1400-1404.

[51] Yoshikawa M, Matsuda H, Morikawa T, Xie H, Nakamura S and Muraoka O. Phenylethanoid oligoglycosides and acylated oligosugars with vasorelaxant activity from Cistanche tubulosa. Bioorg Med Chem 2006;14(22):7468-7475.

[52] Rahbar AR and Nabipour I. The hypolipidemic effect of Citrullus colocynthis on patients with hyperlipidemia. Pak J Biol Sci 2010; 13(24):1202-1207.

[53] Al-Snafi AE. Chemical constituents and pharmacological effects of Citrullus colocynthis - A review. IOSR Journal of Pharmacy 2016; 6(3): 57-67.

[54] Amamou F, Bouafia M, Chabane-Sari D, Meziane RK and Nani A. Citrullus colocynthis: a desert plant native in Algeria, effects of fixed oil on blood homeostasis in Wistar rat. J Nat Prod Plant Resour 2011; 1 (3):1-7.

[55] Sanadgo N, Najafi S, Ghasemi LV, Motalleb G and Estakhr J. A study of the inhibitory effects of Citrullus colocynthis (CCT) using hydro-alcoholic extract on the expression of cytokines: TNF- $\alpha$ and IL6 in high fat diet-fed mice towards a cure for diabetes mellitus. Journal of Pharmacognosy and Phytotherapy 2011; 3(6): 81-88.

[56] Kurowska EM and Manthey JA. Hypolipidemic effects and absorption of citrus polymethoxylated flavones in hamsters with diet-induced hypercholesterolemia. J Agric Food Chem 2004; 19: 2879-2886.

[57] Garg A, Garg S, Zaneveld LJD and Singla A. Chemistry and pharmacology of the citrus bioflavonoid hesperidin. Phytotherapy Research 2001; 15(8): 655-669.

[58] Ohnishi A, Asayama R, Mogi M, Nakaoka H, Kan-No H, Tsukuda K, Chisaka T, Wang XL, Bai HY, Shan BS, Kukida M, Iwanami J and Horiuchi M. Drinking citrus fruit juice inhibits vascular remodeling in cuff-induced vascular injury mouse model. PLoS One 2015;10(2):e0117616. doi: 10.1371/journal.pone.0117616.

[59] Akhtar SS. Evaluation of Cardiovascular Effects of Citrus aurantifolia (Linn.) Fruit. Social Science Research Network 2013, http://ssrn.com/abstract=2279447

[60] Souza A, Lamidi M, Ibrahim B, Samseny A, Mounanga MB and M'Batchi. B. Antihypertensive effect of an aqueous extract of Citrus aurantifolia (Rutaceae) (Christm.) Swingle, on the arterial blood pressure of mammal. International Research of Pharmacy and Pharmacology 2011; 1(7): 142-148.

[61] Riaz A, Khan RA, Mirza T, Mustansir T and Ahmed M. In vitro/ in vivo effect of Citrus limon (L. Burm. f.) juice on blood parameters, coagulation and anticoagulation factors in rabbits. Pak $J$ Pharm Sci 2014;27(4):907-915.

[62] Al-Yahya MA, Mothana RA, Al-Said MS, El-Tahir KE, Al-Sohaibani M and Rafatullah S. Citrus medica "Otroj": Attenuates oxidative stress and cardiac dysrhythmia in isoproterenol-induced cardiomyopathy in rats. Nutrients 2013; 5: 4269-4283.

[63] Perez YY, Jimenez-Ferrer E, Alonso D, Botello-Amaro CA and Zamilpa A. Citrus limetta leaves extract antagonizes the hypertensive effect of angiotensin II. Journal of Ethnopharmacology 2010; 128(3): 610614.

[64] Reshef N, Hayari Y, Goren C, Boaz M, Madar Z and Knobler H. Antihypertensive effect of sweetie fruit in patients with stage I hypertension. Am J Hypertens 2005; 18(10): 1360-1363.

[65] Asgary S and Keshvari M. Effects of Citrus sinensis juice on blood pressure. ARYA Atheroscler 2013; 9(1): 98-101.

[66] -Kumamoto H, Matsubara Y, Izuka Y, Okamoto K, Yokoi K. Structure and hypotensive effect of flavonoid glycosides in orange (Citrus sinensis OSBECK) peelings. Agric Biol Chemistry 1986; 50: 781783.

[67] Yaghmaie P, Parivar K and Haftsavar M. Effects of Citrus aurantifolia peel essential oil on serum cholesterol levels in Wistar rats. Journal of Paramedical Sciences (JPS) 2011; 2(1):29-32.

[68] 68-Akinboyewa OM. Effect of Citrus aurantifolia on hepatic lipidomics in female albino rats. BSc thesis, Department of Biochemistry, College of Natural Sciences, Federal University of Agriculture, Abeokuta 2012.

[69] Hiramitsu M, Shimada Y, Kuroyanagi J, Inoue T, Katagiri T, Zang L, Nishimura Y, Nishimura N and Tanaka T. Eriocitrin ameliorates diet-induced hepatic steatosis with activation of mitochondrial biogenesis. Sci Rep 2014; 4: 3708. 
[70] Menichini F, Tundis R, Loizzo MR, Bonesi M, Liu B, Jones P, Persaud SJ, Mastellone V, Lombardi P, Houghton PJ, Avallone L and Menichini F. C. medica cv Diamante peel chemical composition and influence on glucose homeostasis and metabolic parameters. Food Chemistry 2011; 124(3): 1083-1089.

[71] Asnaashari S, Delazar A, Habibi B, Vasfi R, Nahar L, Hamedeyazdan S and Sarker SD. Essential oil from Citrus aurantifolia prevents ketotifen induced weight-gain in mice. Phytotherapy Research 2010; 24(12): 1893, DOI : 10.1002/ptr.3227

[72] YB and Jain SM. Antihyperlipidemic activity of Clitoria ternatea and Vigna mungo in rats. Pharmaceutical Biology 2010; 48(8): 915-923.

[73] Al-Snafi AE. Pharmacological importance of Clitoria ternatea - A review IOSR Journal of Pharmacy 2016; 6(3): 68-83.

[74] Al-Aghawani W, Al-Madi S and Al-Lahham A. The vasodilator effects of Convolvulus arvensis in rabbit isolated aortic rings. Arabic Journal of Pharmaceutical Sciences 2009; 9(3): 39-48.

[75] Al-Snafi AE. The chemical constituents and pharmacological effects of Convolvulus arvensis and Convolvulus scammonia- A review. IOSR Journal of Pharmacy 2016; 6(6): 64-75.

[76] Al-Aghawani W and Al-Madi S. Study the vasodilator effect at molecular level of Convolvulus arvensis in isolated aortic rings. Damascus Journal of health Sciences 2010; 26(1): 601-620.

[77] Khare CP. Indian medicinal plants, an illustrated dictionary. Springer Science and Business Media, LLC 2007: 171-172.

[78] Al-Snafi AE. The contents and pharmacological importance of Corchorus capsularis- A review. IOSR Journal of Pharmacy 2016; 6(6): 58-63.

[79] Patel RP and Patel M. Cardiotonic activity of isolated cardiac glycoside from fruit of Linn. Int Res J Pharm 2013; 3(7): 239-242.

[80] -Dhanalakshmi R and Manavalan R. In silico docking approach for antiathero-seclerosis of and admet prediction. Asian J Pharm Clin Res 2015; 8(2): 350-353.

[81] Frerejacque M and Durgeat M. Digitalis like poisons of jute seed. Compt Rend 1954; 238:507-509.

[82] -Al-Snafi AE. The contents and pharmacological importance of Corchorus capsularis- A review. IOSR Journal of Pharmacy 2016; 6(6): 58-63.

[83] Karrer P and Banergee P. Corchortoxinm a cardiac agent from jute seeds. Helv Chim Acta 1949; 32:2385-2392.

[84] -Negm S, EI-Shabrawy O, Arbid M and Radwan AS. Toxicological study of the different organs of Corchorus olitorius L. plant with special reference to their cardiac glycosides content. Zeitsc Ernaehrungsw 1980; 19(1): 28-32.

[85] Rao EV, Rao DV, Pavanaram SK, von Euw J and Reichstein T. Structure of Corchoroside $\beta$ Glycosides and aglycones. Helv Chim Acta 1971; 54(7): 1960-1968.

[86] Rao MR Liu TP and Meng ZJ. Comparative studies on the cardiotonic action of corchoroside A, ouabain and strophanthin $\mathrm{K}$ on the heart-lung preparation of guinea pig and cat. Yao Xue Xue Bao 1979; 14(5): 257-266.

[87] -Abuo-Shaaban RR, Angari AA, El-Tahir KE, Al-KhamisKI and Mirghani OM. Comparative hypotensive and respiratory stimulation effects of ripe and unripe fruit mucilage of Cordia myxa and Cordia obliqua in guineapigs and rabbits. Phytotherapy Res 1989; 3(4): 126-131.

[88] Al-Snafi AE. The Pharmacological and therapeutic importance of Cordia myxa- A review. IOSR Journal of Pharmacy 2016; 6(6): 47-57.

[89] Jabeen Q, Bashir S, Lyoussi B and Gilani AH. Coriander fruit exhibits gut modulatory, blood pressure lowering and diuretic activities. J Ethnopharmacol 2009;122(1):123-130.

[90] Medhin DG, Bakos P and Hadházy P. Inhibitory effects of extracts of Lupinus termis and Coriandrum sativum on electrically induced contraction of the rabbit ear artery. Acta Pharm Hung 1986; 56(3): 109. 113.

[91] Medhin DG, Hadhazy P, Bakos P and VerzarPetri G.Hypotensive effects of Lupinus termis and C oriandrum sativum in anesthetized rats: preliminary study. Acta Pharmaceutica Hungarica 1986; 56(2): 59-63.

[92] Patel DK, Desai SN, Gandhi HP, Devkar RV and Ramachandran AV. Cardio protective effect of Coriandrum sativum L. on isoproterenol induced myocardial necrosis in rats. Food Chem Toxicol 2012;50(9):3120-3125.

[93] Kousar S, Jahan N, Khalil-ur-Rehman and Nosheen S. Antilipidemic activity of Coriandrum sativum. Bioscience Research 2011; 8(1): 8-14.

[94] Joshi SC, Sharma N and Sharma P. Antioxidant and lipid lowering effect of Coriandrum sativum in cholesterol fed rabbits. Int J Pharm Pharm Sci 2012; 4(3):231-234.

[95] La AA, Kumar T, Murthy PB and Pillai KS. Hypolipidemic effect of Coriandrum sativum L. in tritoninduced hyperlipidemic rats. Indian J Exp Biol 2004; 42(9): 909-912. 
[96] Chithra V and Leelamma S. Coriandrum sativum has antioxidant activity. J Nutr Biochem 2009;20(11):901-908.

[97] Dhanapakiam P, Joseph JM, Ramaswamy VK, Moorthi M and Kumar AS. Coriandor seeds have a cholesterollowering action. J Environ Biol 2008;29(1):53-56.

[98] Chithra V and Leelamma S. Hypolipidemic effect of coriander seeds (Coriandrum sativum): mechanism of action. Plant Foods Hum Nutr 1997;51(2):167-172.

[99] Ertas ON, Guler T, Cftc M, Dalklc B and Ylmaz O. The effect of a dietary supplement coriander seeds on the fatty acid composition of breast muscle in Japanese quail. Revue de Médecine Vétérinaire. 2005; 156(10): 514-518.

[100] Patel D, Desai S, Gajaria T, Devkar R and Ramachandran AV. Coriandrum sativum L. seeds extract mitigates lipotoxicity in raw 264.7 cells and prevents atherogenic changes in rats. EXCLI Journal 2013; 12: 313-334.

[101] -United States Dispensatory- 1918: 183-184. The Southwest School of Botanical Medicine http://www.swsbm.com

[102] Slavík J, Zácková P, Michlová J, Opletal L and Sovová M. Phytotherapeutic aspects of diseases of the circulatory system. III. Cardiotonic and cardiotoxic effects of hyrcanoside and deglucohyrcanoside isolated from Coronilla varia L. Ceska Slov Farm 1994;43(6):298-302.

[103] Zácková P, Sovová M, Horáková M and Opletalová V. Study of Coronilla varia L. III. Pharmacological evaluation of its effects on heart function. Cesk Farm 1982; 31(6):242-246.

[104] Gersl V. Effects of Coronilla varia Linné extract and lanatoside C in rabbits with experimental acute heart overloading in vivo. Sb Ved Pr Lek Fak Karlovy Univerzity Hradci Kralove 1980; 23(4): 445-457.

[105] Biletskyi I. Cardiac glycosides from Coroilla varia. Farm Zh 1964; 19: 22-25.

[106] Mráz M, Opletal L, Sovová M, DraŜar P and Havel M. Inhibition of $\mathrm{Na}^{+}, \mathrm{K}^{+}$-ATPase by the glycosides from Coronilla varia. Planta Med 1992; 58(5): 467-468.

[107] Chahine N, Hanna J, Makhlouf H, Duca L, Martiny L and Chahine R. Protective effect of saffron extract against doxorubicin cardiotoxicity in isolated rabbit heart. Pharm Biol 2013;51(12):15641571.

[108] Al-Snafi AE. The pharmacology of Crocus sativus- A review. IOSR Journal of Pharmacy 2016; 6(6): 838.

[109] Mehdizadeh R, Parizadeh MR, Khooei AR, Mehri S and Hosseinzadeh H. Cardioprotective effect of saffron extract and safranal in isoproterenol-induced myocardial infarction in wistar rats. Iran $\mathbf{J}$ Basic Med Sci 2013; 16(1): 56-63.

[110] Sachdeva J, Tanwar V, Golechha M, Siddiqui KM, Nag TC, Ray R, Kumari S and Arya DS. Crocus sativus L. (saffron) attenuates isoproterenol-induced myocardial injury via preserving cardiac functions and strengthening antioxidant defense system. Exp Toxicol Pathol 2012; 64(6): 557-564.

[111] Liu N, Yang Y, Mo S, Liao J and Jin J.Calcium antagonistic effects of Chinese crude drugs: Preliminary investigation and evaluation by 45Ca. Applied Radiation and Isotopes 2005; 63:151-155.

[112] Khori V, Alizadeh AM, Yazdi H, Rakhshan E, Mirabbasi A, Changizi S, Mazandarani M and Nayebpour M. Frequency-dependent electrophysiological remodeling of the AV node by hydroalcohol extract of Crocus sativus L. (saffron) during experimental atrial fibrillation: the role of endogenous nitric oxide. Phytother Res 2012; 26(6): 826-832.

[113] Boskabady MH, Shafei MN, Shakiba A and Sefidi HS. Effect of aqueous-ethanol extract from Crocus sativus (saffron) on guinea-pig isolated heart. Phytother Res 2008; 22(3): 330-334.

[114] Fatehi M, Rashidabady T and Fatehi-Hassanabad Z. Effects of Crocus sativus petals' extract on rat blood pressure and on responses induced by electrical field stimulation in the rat isolated vas deferens and guinea-pig ileum. J Ethnopharmacol 2003; 84(2-3): 199-203.

[115] Imenshahidi M, Hosseinzadeh $\mathrm{H}$ and Javadpour $\mathrm{Y}$. Hypotensive effect of aqueous saffron extract (Crocus sativus L.) and its constituents, safranal and crocin, in normotensive and hypertensive rats. Phytother Res 2010; 24(7): 990-994.

[116] Imenshahidi M, Razavi BM, Faal A, Gholampoor A, Mousavi SM and Hosseinzadeh H. The effect of chronic administration of saffron (Crocus sativus) stigma aqueous extract on systolic blood pressure in rats. Jundishapur J Nat Pharm Prod 2013; 8(4): 175-179.

[117] Joukar S . Electrocardiogram alterations following one- week consumption of Crocus sativus L.(Saffron). EXCLI Journal 2012; 11: 480-486.

[118] 118-Mousavi M, Baharara J and Shahrokhabadi K. The Synergic Effects of Crocus sativus L. and low frequency electromagnetic field on VEGFR2 gene expression in human breast cancer cells. Avicenna J Med Biotechnol 2014; 6(2): 123-127.

[119] Mancini A, Serrano-Díaz J, Nava E, D'Alessandro AM, Alonso GL, Carmona M and Llorens S. Crocetin, a carotenoid derived from saffron (Crocus sativus L.), improves acetylcholine-induced vascular relaxation in hypertension. J Vasc Res 2014; 51(5): 393-404. 
[120] Sheng L, Qian Z, Zheng S and Xi L. Mechanism of hypolipidemic effect of crocin in rats: crocin inhibits pancreatic lipase. Eur J Pharmacol 2006; 543: 116-122.

[121] Zheng S, Qian Z, Tang F and Sheng L. Suppression of vascular cell adhesion molecule-1 expression by crocetin contributes to attenuation of atherosclerosis in hypercholesterolemic rabbits. Biochem Pharmacol 2005; 70: 1192-1199.

[122] Gainer JW and Chisolm GM. Oxygen diffusion and atherosclerosis. Atherosclerosis 1974; 19:135-138.

[123] He S, Qian Z, Tang F, Wen N, Xu G and Sheng L. Effect of crocin on experimental atherosclerosis in quails and its mechanisms. Life Sciences 2005; 77: 907-921.

[124] Verma SK and Bordia A. Antioxidant property of saffron in man. Indian J Med Sci 1998; 52: $205-207$.

[125] Nishio T, Okugawa H, Kato A, Hashimoto Y, Matsumoto K and Fujioka A. Effect of crocus (Crocus sativus L, Iridaceae) on blood coagulation and fibrinolysis. Shoyakugaku Zasshi 1987; 41: 271-276.

[126] Jessie SW and Krishnakantha TP. Inhibition of human platelet aggregation and membrane lipid peroxidation by food spice, saffron. Mol Cell Biochem 2005; 278(1-2):59-63.

[127] Gout B, Bourges C and Paineau-Dubreuil S. Satiereal, a Crocus sativus L extract, reduces snacking and increases satiety in a randomizedplacebo-controlled study of mildly overweight, healthy women. Nutr Res 2010; 30(5): 305-313.

[128] Kumar DS, David B, Harani A and Vijay B. Role of an ethanolic extract of Crotalaria juncea L. on high-fat diet-induced hypercholesterolemia. Sci Pharm 2014; 82(2): 393-409.

[129] Al-Snafi AE. The contents and pharmacology of Crotalaria juncea- A review. IOSR Journal of Pharmacy 2016; 6(6): 77-86.

[130] Harikumar K, Niveditha B, Kumar MRB, Monica K and Gajendra B. Anti- hyperlipidemic activity of alcoholic and methanolic extracts of Crotolaria juncea in Triton-WR 1339 induced hyperlipidemia. International Journal of Phytopharmacology 2012; 3(3): 256-262.

[131] Prasad J, Singh VK, Shrivastava A, Chaturvedi U, Bhatia G, Arya KR, Awasthi SK and Narender T. Antidyslipidemic and antioxidant activity of an unusual amino acid (2-amino-5-hydroxyhexanoic acid) isolated from the seeds of Crotalaria juncea. Phytomedicine 2013;21(1):15-19.

[132] Sreedhar KS. Evaluation of Anti-obesity activities of Crotalaria juncea L. in albino rats. MSc thesis, Gautham College of Pharmacy 2011.

[133] Srivastava KC. Extracts from two frequently consumed spices-cumin (Cuminum cyminum) and turmeric (Curcuma longa)- inhibit platelet aggregation and alter eicosanoid biosynthesis in human blood platelets. Prostaglandins Leukot Essent Fatty Acids 1989; 37(1):57-64.

[134] Al-Snafi AE. The pharmacological activities of Cuminum cyminum - A review. IOSR Journal of Pharmacy 2016; 6(6): 46-65.

[135] Kalaivani P, Saranya RB, Ramakrishnan G, Ranju V, Sathiya S, Gayathri V, Thiyagarajan LK, Venkhatesh JR, Babu CS and Thanikachalam S. Cuminum cyminum, a dietary spice, attenuates hypertension via endothelial nitric oxide synthase and NO pathway in renovascular hypertensive rats. Clin Exp Hypertens 2013; 35(7): 534-542.

[136] Shirke SS and Jagtap AJ. Effects of methanolic extract of Cuminum cyminum on total serum cholesterol in ovariectomized rats. Indian J Pharmacol 2009; 41(2): 91-93.

[137] Zare R, Heshmati F, Fallahzadeh H and Nadjarzadeh A. Effect of cumin powder on body composition and lipid profile in overweight and obese women. Complement Ther Clin Pract 2014; 20(4): 297-301.

[138] Samani KG and Farrokhi E. Effects of cumin extract on oxLDL, paraoxanase 1 activity, FBS, total cholesterol, triglycerides, HDL-C, LDL-C, Apo A1, and Apo B in in the patients with hypercholesterolemia. Int J Health Sci (Qassim) 2014; 8(1):39-43.

[139] Taghizadeh M, Memarzadeh MR, Asemi Z and Esmaillzadeh A. Effect of the Cuminum cyminum L intake on weight loss, metabolic profiles and biomarkers of oxidative stress in overweight subjects: A randomized double-blind placebo-controlled clinical trial. Ann Nutr Metab 2015; 66(2-3):117-124.

[140] Karkabounas S, Kiortsis DN, Zelovitis J, Skafida P, Demetzos C, Malamas M, Elisaf M and Evangelou A. Effects of Cupressus sempervirens cone extract on lipid parameters in Wistar rats. In Vivo 2003;17(1):101-103.

[141] Al-Snafi AE. Medical importance of Cupressus sempervirens- A review. IOSR Journal of Pharmacy 2016; 6(6): 66-76.

[142] Ulusal BG, Tufan H, Ulusal AE, Haberal C, Seyhan T, Borman H and Haberal M. Pretreatment with cypress cones water extract enhances survival of ischemically challenged skin flaps a preliminary study. Türk Plastik ve Rekonstrüktif Cerrahi Dergisi 2009; 17(1): 25-29.

[143] Zhou WT, Abdurahman A, Abdusalam E, Yiming W, Abliz P, Aji Q, Issak M, Iskandar G, Moore N and Umar A. Effect of Cydonia oblonga Mill. leaf extracts or captopril on blood pressure and related biomarkers in renal hypertensive rats. J Ethnopharmacol 2014; 153(3): 635-640.

[144] Al-Snafi AE. The medical importance of Cydonia oblonga- A review. IOSR Journal of Pharmacy 2016; 6(6): 87-99. 
[145] Zhou W, Abdusalam E, Abliz P, Reyim N, Tian S, Aji Q, Issak M, Iskandar G, Moore N and Umar A. Effect of Cydonia oblonga Mill fruit and leaf extracts on blood pressure and blood rheology in renal hypertensive rats. J Ethnopharmacol 2014; 152(3): 464-469.

[146] Abliz A, Aji Q, Abdusalam E, Sun X, Abdurahman A, Zhou W, Moore N and Umar A. Effect of Cydonia oblonga Mill leaf extract on serum lipids and liver function in a rat model of hyperlipidaemia. J Ethnopharmaco 2014; 151(2): 970-944.

[147] Umar A, Iskandar G, Aikemu A, Yiming W, Zhou W, Berké B, Begaud B and Moore N. Effects of Cydonia oblonga Miller leaf and fruit flavonoids on blood lipids and anti-oxydant potential in hyperlipidemia rats. J Ethnopharmacol 2015; 169: 239-243.

[148] Khademi F. The efficay of quince leave extract on atherosclerotic plaques induced by atherogenic diet in coronary and aorta, hyperlipidemia and liver in rabbit. MSc thesis, Tabriz University of Medical Sciences, Tabriz, Iran 2009.

[149] Zhou W, Abdurahman A, Umar A, Iskander G, Abdusalam E, Berké B, Bégaud B and Moore N. Effects of Cydonia oblonga Miller extracts on blood hemostasis, coagulation and fibrinolysis in mice, and experimental thrombosis in rats. J Ethnopharmacol 2014; 154(1):163-169.

[150] Rajaretinam RK and Vincent SG. Cynodon dactylon and Sida acuta extracts impact on the function of the zebrafish embryos. J Biomed Res 2012; 26: 90-97.

[151] -Garjani A, Afrooziyan A, Nazemiyeh H, Najafi M, Kharazmkia A and Maleki-Dizaji N. Protective effects of hydroalcoholic extract from rhizomes of Cynodon dactylon (L) Pers on compensated right heart failure in rats. BMC Complement Altern Med 2009; 9: 28-36.

[152] Shabi MM, Raj David C, Sasikala C, Gayathri K and Joseph J. Negative inotropic and chronotropic effects of phenolic fraction from Cynodon dactylon (Linn) on isolated perfused frog heart. Journal of Scientific Research 2012; 4(3): 657-663.

[153] Najafi M, Nazemiyeh H, Ghavimi H, Gharakhani A and Garjani A. Effects of hydroalcoholic extract of Cynodon dactylon (L) pers on ischemia/reperfusion-induced arrhythmias. DARU 2008; 16 (4): 233-238.

[154] Hugar L and Ramesh H. Evaluation of hemostatic effect of Cynodon dactylon Pers in albino rats. Journal of Evolution of Medical and Dental Sciences 2014; 3(11): 2711-2713.

[155] Al-Snafi AE. Chemical constituents and pharmacological effects of Cynodon dactylon- A review. IOSR Journal Of Pharmacy 2016; 6(7): 17-31.

[156] Al-Snafi AE. A review on Cyperus rotundus A potential medicinal plant. IOSR Journal Of Pharmacy 2016; 6(7): 32-48.

[157] Chandratre RS, Chandarana S and Mengi SA. Lipid lowering activity of alcoholic extract of Cyperus rotundus. IJRPC 2011; 1(4): 1042- 1045.

[158] Nagulendran KR, Mahesh R and Begum VH, Preventive role of Cyperus rotundus rhizomes extract on age associated changes in glucose and lipids, Pharmacologyonline 2007; 2: 318-325.

[159] Lemaure B, Touché A, Zbinden I, Moulin J, Courtois D, Macé K and Darimont C. Administration of Cyperus rotundus tubers extract prevents weight gain in obese Zucker rats. Phytother Res 2007; $21: 724$ 730.

[160] Seo EJ, Lee DU, Kwak JH, Lee SM, Kim YS and Jung YS. Antiplatelet effects of Cyperus rotundus and its component (+)-nootkatone. Journal of Ethnopharmacology 2011; 135: 48-54.

[161] Xue JX, Jiang Y and Yan YQ. Effects of the combination of Astragalus membranaceus (Fisch.) Bge. (AM), tail of Angelica sinensis (Oliv.) Diels. (TAS), Cyperus rotundus L. (CR), Ligusticum chuanxiong Hort. (LC) and Paeonia veitchii Lynch (PV) on the hemorrheological changes in normal rats. Zhongguo Zhong Yao Za Zhi 1993; 18(10): 621-623. 